\title{
Urgently listed lung transplant patients have outcomes similar to those of electively listed patients
}

Andrew Tang, MD, ${ }^{\mathrm{a}}$ Lucy Thuita, MS, ${ }^{\mathrm{b}}$ Hafiz Umair Siddiqui, MD, ${ }^{\mathrm{a}}$ Jesse Rappaport, MD, ${ }^{\mathrm{a}}$ Eugene H. Blackstone, MD, ${ }^{\mathrm{a}, \mathrm{b}}$ Kenneth R. McCurry, MD, ${ }^{\mathrm{a}, \mathrm{d}, \mathrm{d}}$ and Usman Ahmad, MD, ${ }^{\mathrm{a}, \mathrm{c}, \mathrm{d}}$ for the Lung Transplantation Center

\section{ABSTRACT}

Objectives: To (1) determine outcomes after urgent listing compared with elective listing for lung transplant and (2) compare in-hospital morbidity and mortality, survival, and allograft function in these 2 groups.

Methods: From January 2006 to September 2017, 201 patients were urgently and 1423 electively listed. Among urgently listed patients, 130 subsequently underwent primary lung transplant as did 995 electively listed patients. Competing-risks analysis for death and transplant after listing and weighted balancing score matching (76 pairs) were used to compare in-hospital morbidity and survival. Mixed-effect longitudinal modeling was used to compare allograft function to 8 years post-transplant.

Results: At 1 month, mortality was $26 \%$ in urgently listed patients, and $58 \%$ were transplanted. Risk factors for death included older age, higher bilirubin, and transfer from an outside hospital. At transplantation, urgently listed transplant patients were younger ( $53 \pm 13$ vs $55 \pm 12$ years), had more ventilator and extracorporeal membrane oxygenation support ( $32 / 25 \%$ vs $20 / 2.0 \%$ ), more restrictive lung disease ( $95 / 73 \%$ vs 509/51\%), and a higher lung allocation score ( $82 \pm 13$ vs $47 \pm 17)$. Inhospital morbidity and mortality, time-related survival, and longitudinal allograft function were similar between matched groups.

Conclusions: Urgent listing more often than not leads to transplantation. Although urgently listed patients are sicker overall, after transplant their perioperative morbidity and mortality, overall survival, and allograft function are similar to those of electively listed patients. Appropriate patient selection and aggressive supportive care allow urgently listed lung transplant patients to achieve these similar posttransplant outcomes. (J Thorac Cardiovasc Surg 2021;161:306-17)

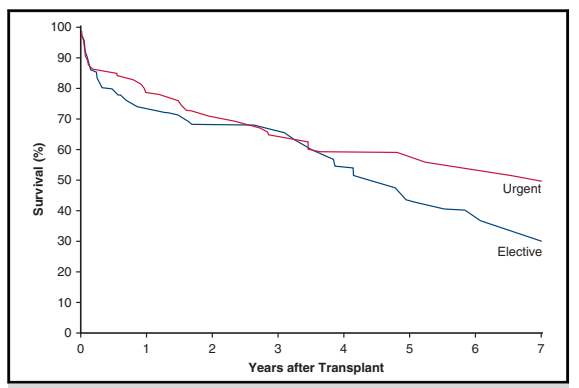

Survival after transplant in urgently (red) and electively (blue) listed matched patients.

\section{CENTRAL MESSAGE}

Most urgently listed patients undergo lung transplant within 1 month. Morbidity, long-term survival, and allograft function after transplant are similar for urgently and electively listed patients.

\section{PERSPECTIVE}

Patients urgently listed for lung transplant are a high-risk group. More than one half proceed to transplant within 1 month of listing. After transplant, they have similar perioperative morbidity, long-term survival, and longitudinal allograft function to electively listed patients. High-volume centers can achieve these similar outcomes with appropriate patient selection and aggressive supportive care.

See Commentaries on pages 318,319 , and 321
From the ${ }^{\mathrm{a}}$ Department of Thoracic and Cardiovascular Surgery, Heart, Vascular and Thoracic Institute, ${ }^{\mathrm{b}}$ Quantitative Health Sciences and ${ }^{\mathrm{d}}$ Department of Inflammation and Immunity, Lerner Research Institute, and ${ }^{\mathrm{c}}$ Transplant Institute, Cleveland Clinic, Cleveland, Ohio.

This study was supported in part by the Gus P. Karos Registry Fund, the Drs Sidney and Becca Fleischer Heart and Vascular Education Chair, and the Daniel and Karen Lee Endowed Chair in Thoracic Surgery. Andrew Tang is a National Heart, Lung, and Blood Institute Clinical Research Scholar of the Cardiothoracic Surgical Trials Network (National Institutes of Health Grant U01 HL088955).
Read at the 99th Annual Meeting of The American Association for Thoracic Surgery, Toronto, Ontario, Canada, May 4-7, 2019.

Received for publication May 7, 2019; revisions received Jan 30, 2020; accepted for publication Feb 14, 2020; available ahead of print April 21, 2020.

Address for reprints: Usman Ahmad, MD, Department of Thoracic and Cardiovascular Surgery, Cleveland Clinic, 9500 Euclid Ave/Desk J4-1, Cleveland, OH 44195 (E-mail: ahmadu@ccf.org).

$0022-5223 / \$ 36.00$

Copyright (C) 2020 by The American Association for Thoracic Surgery

https://doi.org/10.1016/j.jtcvs.2020.02.140 


\section{Abbreviations and Acronyms}

$\mathrm{ECMO}=$ extracorporeal membrane oxygenation

FEV $1 \%=$ forced expiratory volume in 1 second (percent predicted)

LAS = lung allocation score

Scanning this $\mathrm{QR}$ code will take

you to the article title page to access supplementary information. To view the AATS Annual Meeting Webcast, see the URL next to the webcast thumbnail.

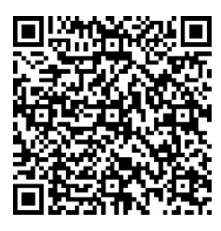

Lung transplant is the ultimate palliative treatment for endstage lung disease. However, organ scarcity continues to be challenging and mandates optimal use of this scarce resource. ${ }^{1}$ Thus, it is imperative to judiciously select recipients to appropriately adjudicate organ allocation and prevent the loss of transplantable organs. ${ }^{2,3}$

Patients who develop acute respiratory deterioration can require urgent and unplanned lung-transplant evaluation. ${ }^{4,5}$ They may require a high level of support and are considered high-risk candidates for transplant. ${ }^{5,6}$ Historically, such high-risk patients have had worse perioperative and longterm survival. ${ }^{4-8}$ For these reasons, not all transplant programs are open to listing patients in respiratory extremis.

As a program that evaluates and lists patients in acute decompensated respiratory failure, our goal was to determine the outcomes after listing these patients for lung transplant. This included studying the competing risk of death on the transplant waitlist and outcomes after urgent transplantation, comparing recipient and donor characteristics, perioperative morbidity and mortality, long-term survival, and allograft function in these urgently listed patients with those of electively listed patients.

\section{METHODS}

This study was approved by the institutional review board (no. 17-1242).

\section{Patients}

From January 2006 to September 2017, 1624 patients were listed for single-organ lung transplant or retransplant, 201 urgently and 1423 electively (Table 1).

\section{Definition of Groups}

The urgently listed group was admitted and listed in the same index hospitalization. The electively listed group underwent routine outpatient evaluation for transplant candidacy and then were listed. They were identified by the date of listing preceding the date of hospital admission for transplantation.

\section{End Points}

End points after listing were death, transplant, or delisting, which were treated as mutually exclusive competing events. For urgently listed patients, median follow-up was 9 days (15th, 85th percentiles: 3,30 ), with 14 patient-years of data available for analysis. For electively listed patients, median follow-up was 3.2 months (17 days, 1.4 years), with 1051 patientyears of data available for analysis.

Primary outcomes after transplant were survival and allograft function, as measured by percent of predicted forced expiratory volume in 1 second (FEV1\%). Time zero for transplanted patients was date of transplant. Patients undergoing retransplantation were censored at date of retransplantation and treated as a separate observation for this subsequent transplant. For urgently transplanted patients, median follow-up was 2.7 years $(6.7$ months, 5.9 years), with 405 patient-years of data available for analysis. For electively transplanted patients, median follow-up was 3.2 years (1.0, 7.5 years), with 3897 patient-years of data available for analysis. For FEV1\% after transplant, 28,762 spirometry records were available for 1018 patients ( $90 \%$ of study cohort; Figure E1).

Secondary outcomes were competing events after urgent listing, inhospital morbidity and mortality, and primary graft dysfunction at 0,24 , 48, and 72 hours after transplant.

\section{Data Analysis}

All analyses were performed using SAS version 9.4 (SAS Institute, Inc, Cary, NC) and R software version 3.3.2 (R Foundation for Statistical Computing, Vienna, Austria). Continuous variables are summarized as mean \pm standard deviation or as equivalent 15th, 50th (median), and 85th percentiles when the distribution of values was skewed; comparisons were made using the Wilcoxon rank-sum test. Categorical variables are summarized as frequencies and percentages; comparisons were made using the $\chi^{2}$ test or Fisher's exact test when there were fewer than 5 observations.

\section{Competing Risk on Waitlist}

To estimate the likelihood of experiencing death, transplant, or delisting while on the waitlist, competing-risks analysis was used. ${ }^{9}$ A parametric nonproportional hazards method was used to resolve the number of phases of instantaneous risk of death and transplant after listing (hazard) for the urgently transplanted patients and to estimate shaping parameters. Incremental risk factors for each of these waitlist end points were identified by the machine learning method described by Rajeswaran and Blackstone $^{10}$ using 1000 bootstrap data sets and the variables listed in Appendix E1.

\section{Matched Comparison of Transplanted Groups}

Because characteristics of the urgently and electively listed groups differed substantially at transplantation (Table 2), weighted balancingscore methodology was used. ${ }^{11}$ This first entailed developing a parsimonious logistic regression model using machine learning variable selection as described previously ${ }^{10}$ and the variables listed in Appendix E2.

Factors associated with urgent versus elective listing included higher lung allocation score (LAS), higher blood urea nitrogen, and higher creatinine clearance, history of diabetes, and being in-hospital and in the intensive care unit (Table E1). This model was augmented with variables also believed to be of clinical importance (see Appendix E2). The C-statistic for the parsimonious model was 0.95 and for the augmented saturated model, 0.96. Because of the substantial difference between these groups, weighted equivalent number of pairs was 77 and 76 for the urgent and electively transplanted groups, respectively (Figure E2).

\section{Survival After Transplant}

Survival after transplant was estimated nonparametrically using the Kaplan-Meier method and compared using the log-rank test. Survival for 
TABLE 1. Baseline characteristics at time of listing: urgently and electively listed patients

\begin{tabular}{|c|c|c|c|c|c|}
\hline \multirow[b]{2}{*}{ Characteristic } & \multicolumn{2}{|c|}{ Urgently listed $(n=201)$} & \multicolumn{2}{|c|}{ Electively listed $(n=1423)$} & \multirow{2}{*}{$\begin{array}{c}\text { Standardized } \\
\text { difference }\end{array}$} \\
\hline & $\overline{\mathbf{n}^{*}}$ & Mean \pm SD or No. $(\%)$ & $\mathbf{n}^{*}$ & Mean \pm SD or No. $(\%)$ & \\
\hline \multicolumn{6}{|l|}{ Demographics } \\
\hline Age, y & 201 & $54 \pm 13$ & 1423 & $57 \pm 13$ & -22 \\
\hline Female & 201 & $62(31)$ & 1423 & $566(40)$ & -19 \\
\hline Race & 185 & & 1412 & & \\
\hline White & & $158(85)$ & & $1283(91)$ & -17 \\
\hline Black & & $14(7.6)$ & & $89(6.3)$ & 5.0 \\
\hline Other & & $13(7.0)$ & & $40(2.8)$ & 19 \\
\hline Height, $\mathrm{cm}$ & 201 & $171 \pm 10$ & 1414 & $170 \pm 9.7$ & 18 \\
\hline Weight, kg & 200 & $76 \pm 18$ & 1418 & $74 \pm 17$ & 7.8 \\
\hline Weight/height ratio & 200 & $0.44 \pm 0.09$ & 1414 & $0.44 \pm 0.08$ & 4.0 \\
\hline Body surface area, $\mathrm{m}^{2}$ & 200 & $1.9 \pm 0.28$ & 1414 & $1.9 \pm 0.26$ & 8.5 \\
\hline Body mass index, $\mathrm{kg} / \mathrm{m}^{2}$ & 200 & $26 \pm 4.9$ & 1414 & $26 \pm 4.5$ & -1.2 \\
\hline Blood type & 201 & & 1417 & & \\
\hline A & & $61(30)$ & & $564(40)$ & -20 \\
\hline $\mathrm{AB}$ & & $13(6.5)$ & & $43(3.0)$ & 16 \\
\hline B & & $30(15)$ & & $153(11)$ & 12 \\
\hline $\mathrm{O}$ & & $97(48)$ & & $657(46)$ & 3.8 \\
\hline \multicolumn{6}{|l|}{ Medical history } \\
\hline Diabetes & 201 & $77(38)$ & 1422 & 277 (19) & 42 \\
\hline Hypertension & 199 & $80(40)$ & 1052 & $383(36)$ & 7.8 \\
\hline History of smoking & 201 & $122(61)$ & 1419 & $916(65)$ & -8.0 \\
\hline Functional status & 201 & & 1393 & & \\
\hline Disabled or $<50 \%$ Karnofsky score & & $160(80)$ & & $42(3.0)$ & 247 \\
\hline Unable or $50 \%-70 \%$ Karnofsky score & & $41(20)$ & & $1116(80)$ & -149 \\
\hline Able or $\geq 80 \%$ Karnofsky score & & $0(0)$ & & 235 (17) & -64 \\
\hline \multicolumn{6}{|l|}{ Primary diagnosis } \\
\hline Restrictive lung disease & 201 & $153(76)$ & 1423 & $679(48)$ & 61 \\
\hline Cystic fibrosis and immunodeficiencies & 201 & $29(14)$ & 1423 & $233(16)$ & -5.4 \\
\hline Pulmonary vascular disease & 201 & $11(5.5)$ & 1423 & $84(5.9)$ & -1.9 \\
\hline Obstructive lung disease & 201 & $8(4.0)$ & 1423 & $427(30)$ & -74 \\
\hline Lung allocation score & 199 & $82 \pm 14$ & 1058 & $46 \pm 20$ & 215 \\
\hline \multicolumn{6}{|l|}{ Life support } \\
\hline Ventilator & 201 & $98(49)$ & 1419 & $15(1.1)$ & 132 \\
\hline ECMO & 201 & $45(22)$ & 1419 & $2(0.14)$ & 75 \\
\hline On inotropes & 116 & $52(45)$ & 0 & $0(0)$ & - \\
\hline \multicolumn{6}{|l|}{ Pulmonary function and gases } \\
\hline FEV1, \% predicted & 143 & $49 \pm 20$ & 1056 & $38 \pm 22$ & 52 \\
\hline FVC, $\%$ predicted & 139 & $51 \pm 20$ & 1056 & $49 \pm 18$ & 10 \\
\hline Partial carbon dioxide & 149 & $51 \pm 21$ & 1057 & $47 \pm 14$ & 22 \\
\hline Oxygen & 148 & $100 \pm 62$ & 1055 & $59 \pm 29$ & 84 \\
\hline \multicolumn{6}{|l|}{ Renal } \\
\hline Creatinine, $\mathrm{mg} / \mathrm{dL}$ & 200 & $0.85 \pm 0.50$ & 1095 & $0.84 \pm 0.32$ & 1.5 \\
\hline Creatinine clearance, $\mathrm{mL} / \mathrm{min}$ & 199 & $121 \pm 55$ & 1092 & $102 \pm 32$ & 42 \\
\hline $\mathrm{GFR}, \mathrm{mL} / \mathrm{min} / 1.73 \mathrm{~m}^{2}$ & 200 & $120 \pm 59$ & 1095 & $101 \pm 34$ & 40 \\
\hline \multicolumn{6}{|l|}{ Liver } \\
\hline Bilirubin, mg/dL & 200 & $0.50[0.20,1.1] \dagger$ & - & - & - \\
\hline MELD score & 196 & $8.9 \pm 3.9$ & - & - & - \\
\hline International normalized ratio & 196 & $1.1 \pm 0.23$ & - & - & - \\
\hline Albumin, g/dL & 199 & $3.1 \pm 0.64$ & 1088 & $4.1 \pm 0.52$ & -166 \\
\hline \multicolumn{6}{|l|}{ Hemodynamics } \\
\hline \multicolumn{6}{|l|}{ Pulmonary artery pressure, $\mathrm{mm} \mathrm{Hg}$} \\
\hline Diastolic & 185 & $23 \pm 9.9$ & 1313 & $20 \pm 9.3$ & 34 \\
\hline
\end{tabular}


TABLE 1. Continued

\begin{tabular}{|c|c|c|c|c|c|}
\hline \multirow[b]{2}{*}{ Characteristic } & \multicolumn{2}{|c|}{ Urgently listed $(n=201)$} & \multicolumn{2}{|c|}{ Electively listed $(n=1423)$} & \multirow{2}{*}{$\begin{array}{c}\text { Standardized } \\
\text { difference }\end{array}$} \\
\hline & $\mathbf{n}^{*}$ & Mean \pm SD or No. $(\%)$ & $\mathbf{n}^{*}$ & Mean \pm SD or No. $(\%)$ & \\
\hline Systolic & 185 & $53 \pm 20$ & 1320 & $45 \pm 17$ & 43 \\
\hline Mean & 185 & $33 \pm 13$ & 1219 & $29 \pm 11$ & 31 \\
\hline Wedge pressure, $\mathrm{mm} \mathrm{Hg}$ & 179 & $11 \pm 5.6$ & 1296 & $12 \pm 5.3$ & -16 \\
\hline Left ventricular ejection fraction, $\%$ & 179 & $61 \pm 12$ & - & - & - \\
\hline \multicolumn{6}{|l|}{ Hospitalization } \\
\hline Transfer from another institution & 201 & $46(23)$ & 0 & $0(0)$ & - \\
\hline History of transfusion & 178 & $56(32)$ & 0 & $0(0)$ & - \\
\hline \multicolumn{6}{|l|}{ Experience } \\
\hline Time from January 1, 2006, to listing, y & 201 & $7.2 \pm 2.8$ & 1423 & $5.8 \pm 3.2$ & 43 \\
\hline
\end{tabular}

$S D$, Standard deviation; $E C M O$, extracorporeal membrane oxygenation; $F E V I$, forced expiratory volume in 1 second; $F V C$, forced vital capacity; GFR, glomerular filtration rate; MELD, model for end-stage liver disease. *Patients with data available. †Median [15th, 85th percentiles].

the urgently listed group was also estimated parametrically by multiphase hazard function methodology. ${ }^{12}$ To identify risk factors for death after urgently listed transplantation, multivariable analysis was performed in the multiphase hazard function domain. Variables were selected using the method of Rajeswaran and Blackstone ${ }^{10}$ from among those listed in Appendix E2 on the basis of 1000 bootstrap samples.

\section{Spirometry After Transplant}

Temporal change in longitudinal measurements of post-lung transplant FEV $1 \%$ was analyzed using the temporal decomposition method described by Rajeswaran and Blackstone. ${ }^{13}$

\section{Missing Data}

Multiple imputation using the Markov chain Monte Carlo technique ${ }^{14}$ to impute missing values is employed to produce 5 data sets. In multivariable modeling, for each imputed complete data set, we estimated regression coefficients and their variance-covariance matrix. Then, following Rubin, ${ }^{14}$ we combined estimates from the 5 models to yield final regression coefficient estimates, the variance-covariance matrix, and $P$ values.

\section{RESULTS}

\section{Outcomes After Listing}

Of the 201 urgently listed patients, 66 died on the waitlist, 5 were delisted, 130 underwent primary lung transplant, and 55 died after lung transplant (Figure 1 and Figure E3). At 1 month, mortality on the waitlist was $26 \%$, and $58 \%$ had been transplanted (Figure 2). Of the 1423 electively listed patients, 164 died on the waitlist, 164 were delisted, and 995 underwent primary lung transplant (see Figures 1 and E3). At 1 month, mortality was $2.1 \%$, and $20 \%$ had been transplanted (Figure E4).

\section{Risk Factors for Death or Transplant After Urgent Listing}

Instantaneous risk of death after urgent listing had an early and a constant hazard phase. The early phase peaked about 1 to 2 weeks after listing (Figure E5, A). Risk factors for death on the waitlist during the early phase included older age, higher bilirubin, and transfer from an outside hospital (Table E2). In the constant phase, the only risk factor was higher model for end-stage liver disease score.
There was an early instantaneous hazard phase of transplant after urgent listing that peaked at the time of listing and gradually decreased at 3 months (Figure E5, B). Patients transferred from outside hospitals, those with a history of transfusion, and those on inotropic support were less likely to undergo transplant after urgent listing (see Table E2), and patients with a higher estimated glomerular filtration rate were more likely to receive transplant after urgent listing.

\section{Differences in Urgent and Electively Listed Transplant Patients}

At transplant, urgently listed patients were younger than electively listed patients, with lower albumin, more diabetes, higher estimated glomerular filtration rate and creatinine clearance, lower preoperative hematocrit, fewer platelets, more preoperative transfusions, higher total bilirubin and model for end-stage liver disease score, higher preoperative FEV1\%, more preoperative vasopressor support, greater mean pulmonary arterial pressure, greater prevalence of intubation, more extracorporeal membrane oxygenation (ECMO) support, higher LAS, less obstructive lung disease, and more restrictive lung disease (see Table 2). Urgently listed transplant patients underwent more doublelung transplants with similar donor profiles compared with electively listed patients (see Table 2).

\section{In-Hospital Morbidity and Mortality After Transplant}

Perioperatively, matched urgent and electively listed transplant patients had similar in-hospital atrial fibrillation/flutter, postoperative myocardial infarctions, reoperation for bleeding, reoperation for tamponade, respiratory distress/failure, and stroke (Table E3). Intra- and postoperative ECMO was similar between groups as well. Urgently listed transplant patients had similar primary graft dysfunction at time 0,24 , and 72 hours. Intensive care unit and 
TABLE 2. Baseline characteristics at time of transplant before and after weighted propensity matching: urgently and electively listed patients

\begin{tabular}{|c|c|c|c|c|c|c|c|c|c|c|}
\hline \multirow[b]{3}{*}{ Characteristic } & \multicolumn{5}{|c|}{ Before matching } & \multicolumn{5}{|c|}{ After weighted propensity matching } \\
\hline & \multicolumn{2}{|c|}{$\begin{array}{c}\text { Urgent } \\
\text { transplant } \\
(\mathbf{n}=130)\end{array}$} & \multicolumn{2}{|c|}{$\begin{array}{c}\text { Elective } \\
\text { transplant } \\
(\mathrm{n}=995)\end{array}$} & \multirow[b]{2}{*}{$\begin{array}{l}\text { Standardized } \\
\text { difference }\end{array}$} & \multicolumn{2}{|c|}{$\begin{array}{c}\text { Urgent } \\
\text { transplant } \\
(\mathrm{n}=77)\end{array}$} & \multicolumn{2}{|c|}{$\begin{array}{c}\text { Elective } \\
\text { transplant } \\
(n=76)\end{array}$} & \multirow[b]{2}{*}{$\begin{array}{c}\text { Standardized } \\
\text { difference }\end{array}$} \\
\hline & $\mathbf{n}^{*}$ & $\begin{array}{l}\text { No. }(\%) \text { or } \\
\text { mean } \pm \text { SD }\end{array}$ & $\mathbf{n}^{*}$ & $\begin{array}{l}\text { No. }(\%) \text { or } \\
\text { mean } \pm \text { SD }\end{array}$ & & $\mathbf{n}^{*}$ & $\begin{array}{l}\text { No. }(\%) \text { or } \\
\text { mean } \pm \text { SD }\end{array}$ & n* & $\begin{array}{l}\text { No. }(\%) \text { or } \\
\text { mean } \pm \text { SD }\end{array}$ & \\
\hline \multicolumn{11}{|l|}{ Demographics } \\
\hline Age, y & 130 & $53 \pm 13$ & 995 & $58 \pm 12$ & -39 & 76 & $55 \pm 12$ & 76 & $54 \pm 16$ & 4.5 \\
\hline Female & 130 & $34(26)$ & 995 & $336(34)$ & -17 & 76 & $24(31)$ & 76 & $24 \pm 32$ & -2.8 \\
\hline BMI, $\mathrm{kg} / \mathrm{m}^{2}$ & 130 & $25 \pm 4.6$ & 994 & $25 \pm 4.5$ & 0.10 & 76 & $25 \pm 4.6$ & 76 & $25 \pm 4.5$ & 0.21 \\
\hline \multicolumn{11}{|l|}{ Blood type } \\
\hline A & 130 & $37(28)$ & 993 & $407(41)$ & -26 & 76 & $23(30)$ & 76 & $23(30)$ & 0.9 \\
\hline $\mathrm{AB}$ & 139 & $5(3.8)$ & 993 & $43(4.3)$ & -2.4 & 76 & $3.1(4.1)$ & 76 & $3.2(4.3)$ & -0.7 \\
\hline $\mathrm{B}$ & 130 & $19(15)$ & 993 & $123(12)$ & 6.5 & 76 & $11(14)$ & 76 & $11(14)$ & 0.34 \\
\hline $\mathrm{O}$ & 130 & $69(53)$ & 993 & $420(42)$ & 22 & 76 & $39(51)$ & 76 & $39(52)$ & -0.74 \\
\hline \multicolumn{11}{|l|}{ Medical history } \\
\hline Diabetes & 130 & $54(42)$ & 995 & $202(20)$ & 47 & 76 & $24(32)$ & 76 & $22(28)$ & 7.1 \\
\hline COPD & 130 & $7(5.4)$ & 995 & $138(14)$ & -29 & 76 & $6.5(8.5)$ & 76 & $8.5(11)$ & -9.0 \\
\hline Previous transfusion & 130 & $29(22)$ & 995 & $117(12)$ & 28 & 76 & $13(17)$ & 76 & $14(18)$ & -3.1 \\
\hline Previous tracheostomy & 130 & $25(19)$ & 995 & $18(1.8)$ & 59 & 76 & $6.5(8.5)$ & 76 & $5.8(7.7)$ & 3.0 \\
\hline Functional status & 125 & & 993 & & & 71 & & 73 & & \\
\hline $\begin{array}{r}\text { Disabled or }<50 \% \\
\text { Karnofsky score }\end{array}$ & & $112(90)$ & & $114(12)$ & 243 & & $58(82)$ & & $59(81)$ & 1.7 \\
\hline $\begin{array}{l}\text { Unable or } 50 \%-70 \% \\
\text { Karnofsky score }\end{array}$ & & $13(10)$ & & 718 (77) & -181 & & $13(18)$ & & $13(18)$ & 1.3 \\
\hline $\begin{array}{l}\text { Able or } \geq 80 \% \text { Karnofsky } \\
\text { score }\end{array}$ & & $0(0)$ & & $101(11)$ & -49 & & - & & - & - \\
\hline \multicolumn{11}{|l|}{ Primary diagnosis } \\
\hline Restrictive lung disease & 130 & $95(73)$ & 995 & $509(51)$ & 46 & 76 & $54(70)$ & 76 & $52(69)$ & 3.8 \\
\hline $\begin{array}{l}\text { Cystic fibrosis and } \\
\text { immunodeficiencies }\end{array}$ & 130 & $26(20)$ & 995 & $161(16)$ & 9.9 & 76 & $16(20)$ & 76 & $15(20)$ & -0.10 \\
\hline Pulmonary vascular disease & 130 & $3(2.3)$ & 995 & $49(4.9)$ & -14 & 76 & $1.8(2.4)$ & 76 & $2.4(3.1)$ & -4.8 \\
\hline Obstructive lung disease & 130 & $6(4.6)$ & 995 & $276(28)$ & -66 & 76 & $5.2(6.8)$ & 76 & $5.9(7.8)$ & -3.6 \\
\hline Lung allocation score & 130 & $82 \pm 13$ & 995 & $47 \pm 17$ & 226 & 76 & $78 \pm 15$ & 76 & $79 \pm 17$ & -3.6 \\
\hline \multicolumn{11}{|l|}{ Life support } \\
\hline History of ventilation & 130 & $46(35)$ & 995 & $34(3.4)$ & 88 & 76 & $18(24)$ & 76 & $19(25)$ & -2.3 \\
\hline History of ECMO & 130 & $32(25)$ & 995 & $20(2.0)$ & 70 & 76 & $11(14)$ & 76 & $11(15)$ & -3.4 \\
\hline History of inotropes & 130 & $18(14)$ & 995 & $9(0.9)$ & 51 & 76 & $3.8(5.0)$ & 76 & $4.9(6.4)$ & -6.1 \\
\hline $\begin{array}{l}\text { Pulmonary function and gases } \\
\text { FEV1 ( } \% \text { of predicted) }\end{array}$ & 108 & $48 \pm 20$ & 929 & $43 \pm 23$ & 21 & 53 & $47 \pm 20$ & 72 & $48 \pm 23$ & -6.5 \\
\hline \multicolumn{11}{|l|}{ Renal } \\
\hline Creatinine, mg/dL & 129 & $0.74 \pm 0.28$ & 989 & $0.79 \pm 0.28$ & -18 & 75 & $0.75 \pm 0.29$ & 76 & $0.76 \pm 0.35$ & -3.5 \\
\hline Creatinine clearance, $\mathrm{mL} / \mathrm{min}$ & 129 & $131 \pm 53$ & 989 & $109 \pm 35$ & 50 & 75 & $125 \pm 47$ & 76 & $123 \pm 46$ & 3.3 \\
\hline $\mathrm{GFR}, \mathrm{mL} / \mathrm{min} / 1.73 \mathrm{~m}^{2}$ & 129 & $130 \pm 55$ & 989 & $110 \pm 39$ & 42 & 75 & $127 \pm 50$ & 76 & $126 \pm 56$ & 1.2 \\
\hline \multicolumn{11}{|l|}{ Hemodynamics } \\
\hline $\begin{array}{l}\text { Mean pulmonary artery } \\
\text { pressure, } \mathrm{mm} \mathrm{Hg}\end{array}$ & 119 & $31 \pm 11$ & 888 & $29 \pm 11$ & 25 & 72 & $31 \pm 11$ & 72 & $32 \pm 13$ & -7.5 \\
\hline \multicolumn{11}{|l|}{ Laboratory values } \\
\hline MELD score & 129 & $7.8 \pm 2.3$ & 955 & $7.6 \pm 2.4$ & 11 & 75 & $7.7 \pm 2.3$ & 75 & $7.7 \pm 2.1$ & -1.1 \\
\hline Bilirubin, $\mathrm{mg} / \mathrm{dL} \dagger$ & 129 & $\begin{array}{c}0.40 \\
{[0.20,0.85]}\end{array}$ & 989 & $\begin{array}{c}0.40 \\
{[0.20,0.70]}\end{array}$ & 23 & 75 & $\begin{array}{c}0.40 \\
{[0.20,0.70]}\end{array}$ & 76 & $\begin{array}{c}0.40 \\
{[0.20,0.90]}\end{array}$ & 3.2 \\
\hline Hematocrit, \% & 129 & $32 \pm 6.3$ & 988 & $37 \pm 5.4$ & -84 & 75 & $34 \pm 5.9$ & 76 & $34 \pm 6.8$ & -2.2 \\
\hline Platelets & 129 & $220 \pm 116$ & 988 & $225 \pm 84$ & -4.4 & 75 & $240 \pm 105$ & 76 & $229 \pm 95$ & 11 \\
\hline
\end{tabular}


TABLE 2. Continued

\begin{tabular}{|c|c|c|c|c|c|c|c|c|c|c|}
\hline \multirow[b]{3}{*}{ Characteristic } & \multicolumn{5}{|c|}{ Before matching } & \multicolumn{5}{|c|}{ After weighted propensity matching } \\
\hline & \multicolumn{2}{|c|}{$\begin{array}{c}\text { Urgent } \\
\text { transplant } \\
(\mathbf{n}=\mathbf{1 3 0})\end{array}$} & \multicolumn{2}{|c|}{$\begin{array}{c}\text { Elective } \\
\text { transplant } \\
(\mathrm{n}=995)\end{array}$} & \multirow[b]{2}{*}{$\begin{array}{c}\text { Standardized } \\
\text { difference }\end{array}$} & \multicolumn{2}{|c|}{$\begin{array}{c}\begin{array}{c}\text { Urgent } \\
\text { transplant } \\
(\mathbf{n}=77)\end{array} \\
\end{array}$} & \multicolumn{2}{|c|}{$\begin{array}{c}\text { Elective } \\
\text { transplant } \\
(\mathbf{n}=76)\end{array}$} & \multirow[b]{2}{*}{$\begin{array}{c}\text { Standardized } \\
\text { difference }\end{array}$} \\
\hline & $\mathbf{n}^{*}$ & $\begin{array}{l}\text { No. }(\%) \text { or } \\
\text { mean } \pm \text { SD }\end{array}$ & $\mathbf{n} *$ & $\begin{array}{l}\text { No. }(\%) \text { or } \\
\text { mean } \pm \text { SD }\end{array}$ & & $\mathbf{n}^{*}$ & $\begin{array}{l}\text { No. }(\%) \text { or } \\
\text { mean } \pm \text { SD }\end{array}$ & $\mathbf{n}^{*}$ & $\begin{array}{l}\text { No. }(\%) \text { or } \\
\text { mean } \pm \text { SD }\end{array}$ & \\
\hline INR & 129 & $1.09 \pm 0.21$ & 955 & $1.07 \pm 0.32$ & 5.1 & 75 & $1.1 \pm 0.21$ & 75 & $1.1 \pm 0.15$ & 3.0 \\
\hline Albumin, g/dL & 129 & $3.2 \pm 0.62$ & 988 & $3.8 \pm 0.53$ & -110 & 75 & $3.3 \pm 0.61$ & 76 & $3.3 \pm 0.66$ & -0.12 \\
\hline \multicolumn{11}{|l|}{ Surgical } \\
\hline Double-lung transplant & 130 & $101(78)$ & 995 & $581(58)$ & 42 & 76 & $55(72)$ & 76 & $56(74)$ & -3.3 \\
\hline \multicolumn{11}{|l|}{ Experience } \\
\hline $\begin{array}{l}\text { Time from January } 1,2006 \text { to } \\
\text { transplant, } y\end{array}$ & 130 & $7.1 \pm 3.0$ & 995 & $6.0 \pm 3.2$ & 36 & 76 & $6.7 \pm 3.2$ & 76 & $6.7 \pm 2.7$ & 1.1 \\
\hline Donor age & 129 & $38 \pm 16$ & 976 & $38 \pm 16$ & -0.23 & 75 & $39 \pm 16$ & 75 & $41 \pm 15$ & -11 \\
\hline
\end{tabular}

$S D$, Standard deviation; $B M I$, body mass index; $C O P D$, chronic obstructive pulmonary disease; $E C M O$, extracorporeal membrane oxygenation; $F E V I$, forced expiratory volume in 1 second; GFR, glomerular filtration rate; $M E L D$, model for end-stage liver disease; INR, international normalized ratio. *Percent of times factor appeared in 1000 bootstrap models. $\nmid$ Median [15th, 85th percentiles].

hospital lengths of stay after transplant were similar, as was hospital death $(10[13 \%]$ vs $9[11 \%], P=.8)$.

\section{Survival After Transplant}

Survival after transplant was similar in the urgently listed and electively listed matched patients (Figure 3). Among the urgently listed transplant patients, there was an early and constant hazard phase for death after transplant. Early risk of death peaked at 2 weeks post-transplant (Figure E6). Higher international normalized ratio was the most significant risk factor for death in the early phase (Table E4 and Figure E7, A). In the constant phase, lower albumin and higher bilirubin were the most significant risk factors (Figure $\mathrm{E} 7, B$ and $C$ ).

\section{Allograft Function}

In the overall cohort, there was an early rising phase in FEV $1 \%$, peaking at $71 \%$ at 9 months and then gradually decreasing to $60 \%$ at 5 years. Although FEV1\% was slightly lower for urgently listed transplant patients

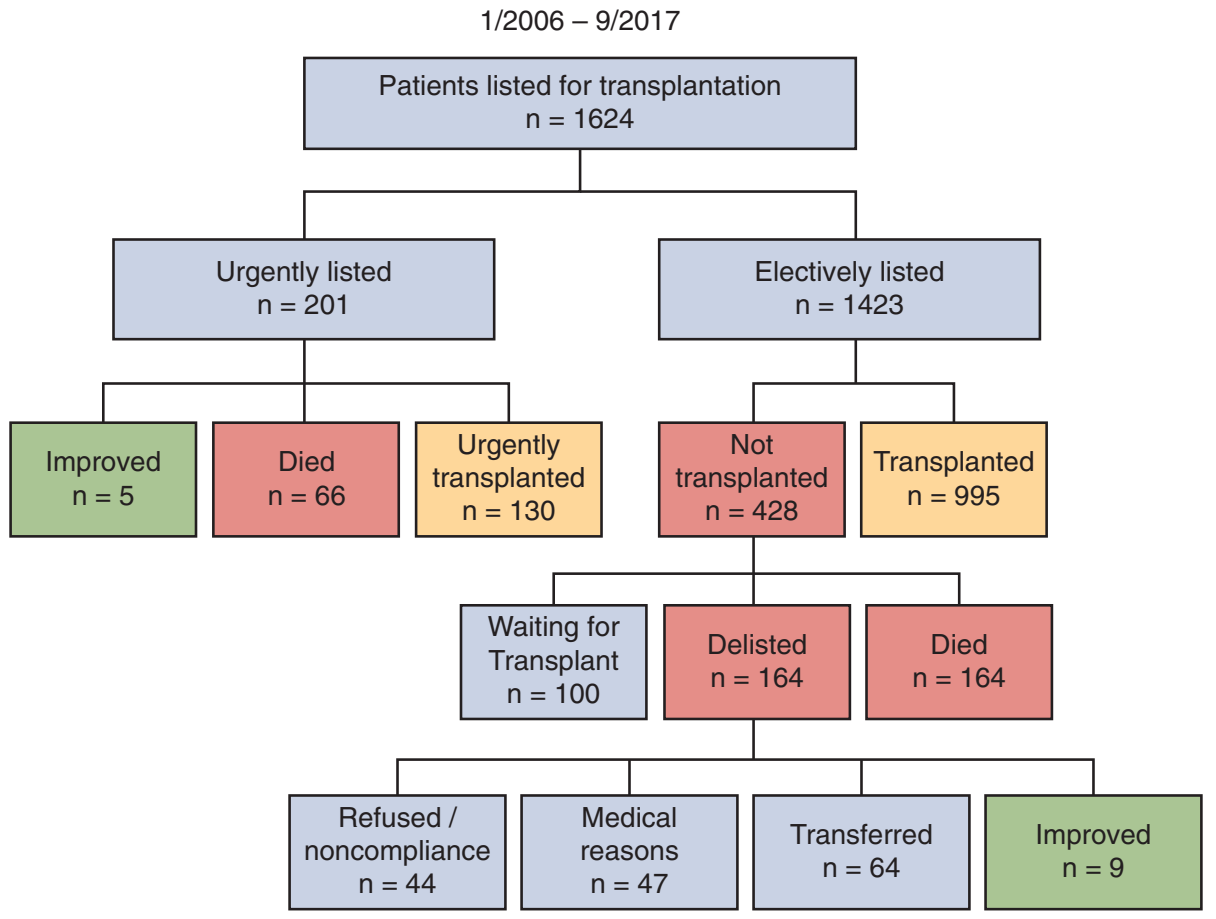

FIGURE 1. CONSORT-style diagram of patients listed for lung transplantation from January 2006 to September 2017, showing the number of patients who were transplanted, died, delisted, or were awaiting lung transplant. 


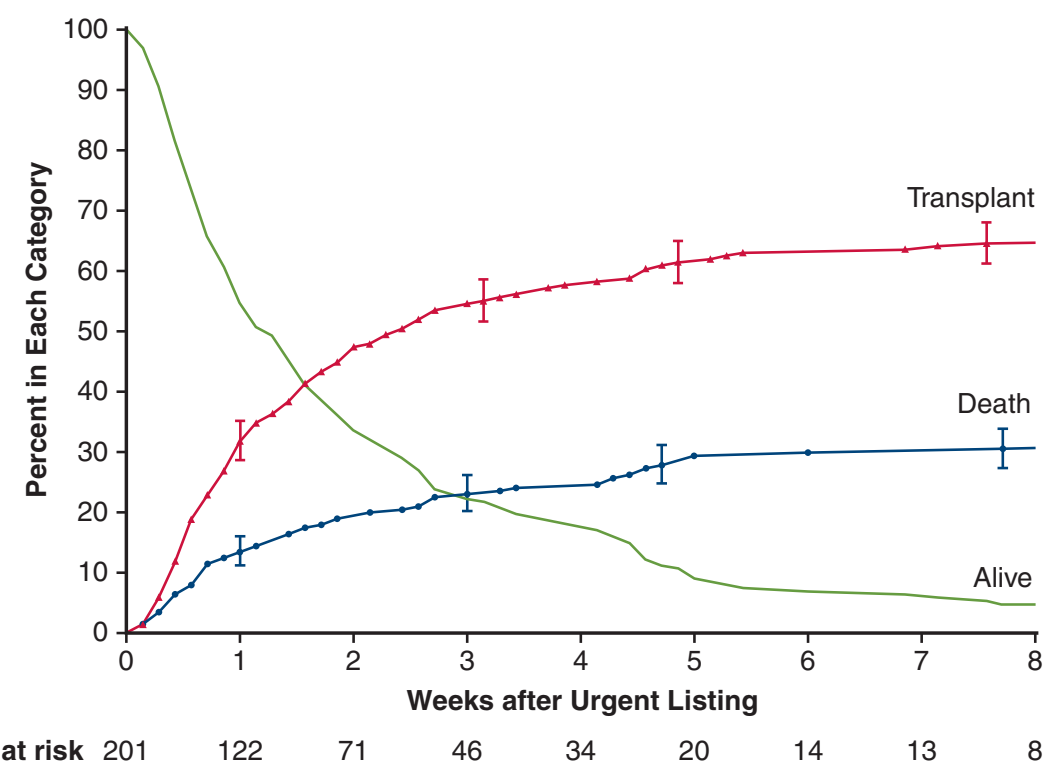

FIGURE 2. Cumulative incidence of transplant (red symbols and line), with death before transplant (blue symbols and line) as a competing risk after urgent listing. Those alive and awaiting transplantation are depicted by the green line. Each symbol represents an event, and vertical bars are $68 \%$ confidence limits (equivalent to \pm 1 standard error).

(Figure 4), there was little difference in either the early phase $(P=.3)$ or the late phase $(P=.06)$.

\section{DISCUSSION}

\section{Principal Findings}

Urgently listed patients rapidly underwent lung transplant within 1 month after listing, although even this short wait was associated with considerable mortality. Patients who were transferred from outside hospitals, required transfusions, needed inotropic support, or were in renal failure were less likely to undergo transplant after urgent listing. Despite being more critically ill, after transplant urgently listed transplant patients had similar perioperative morbidity and mortality, time-related survival, and allograft

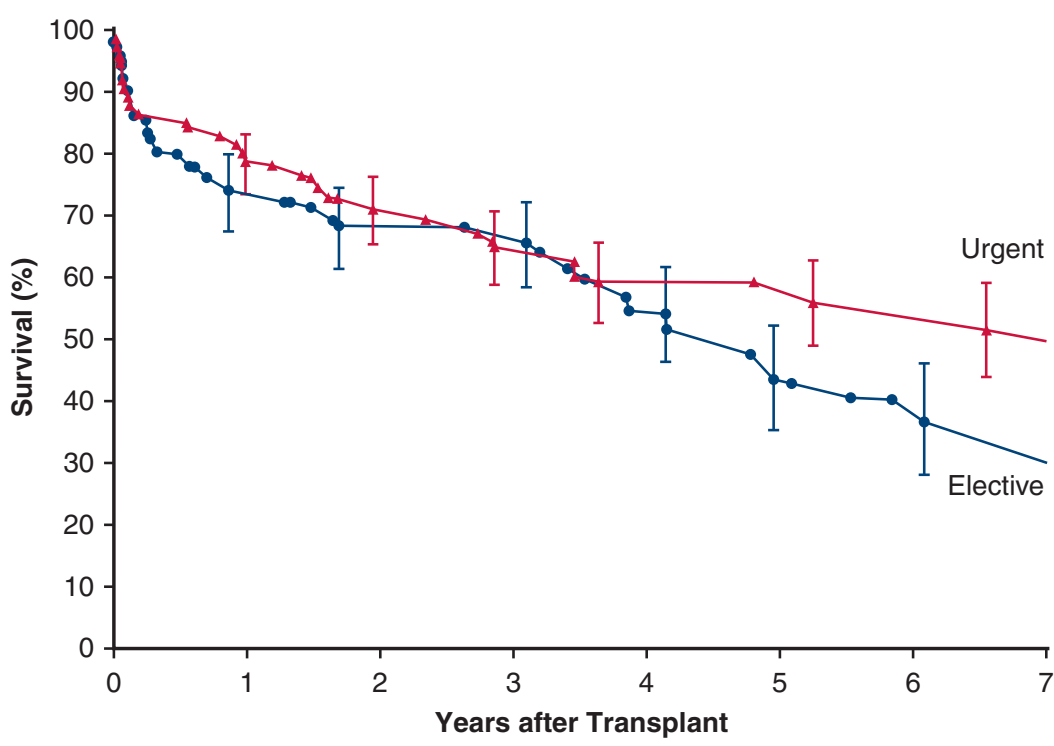

Patients at risk

$\begin{array}{rrrrrrrrr}\text { Urgent } & 76 & 61 & 54 & 42 & 27 & 21 & 18 & 13 \\ \text { Elective } & 76 & 48 & 36 & 30 & 27 & 17 & 11 & 8\end{array}$

FIGURE 3. Kaplan-Meier estimates of survival after transplant in matched urgently listed (red symbols and line) and electively listed (blue symbols and line) patients. Each symbol represents a death, and vertical bars are $68 \%$ confidence limits. 


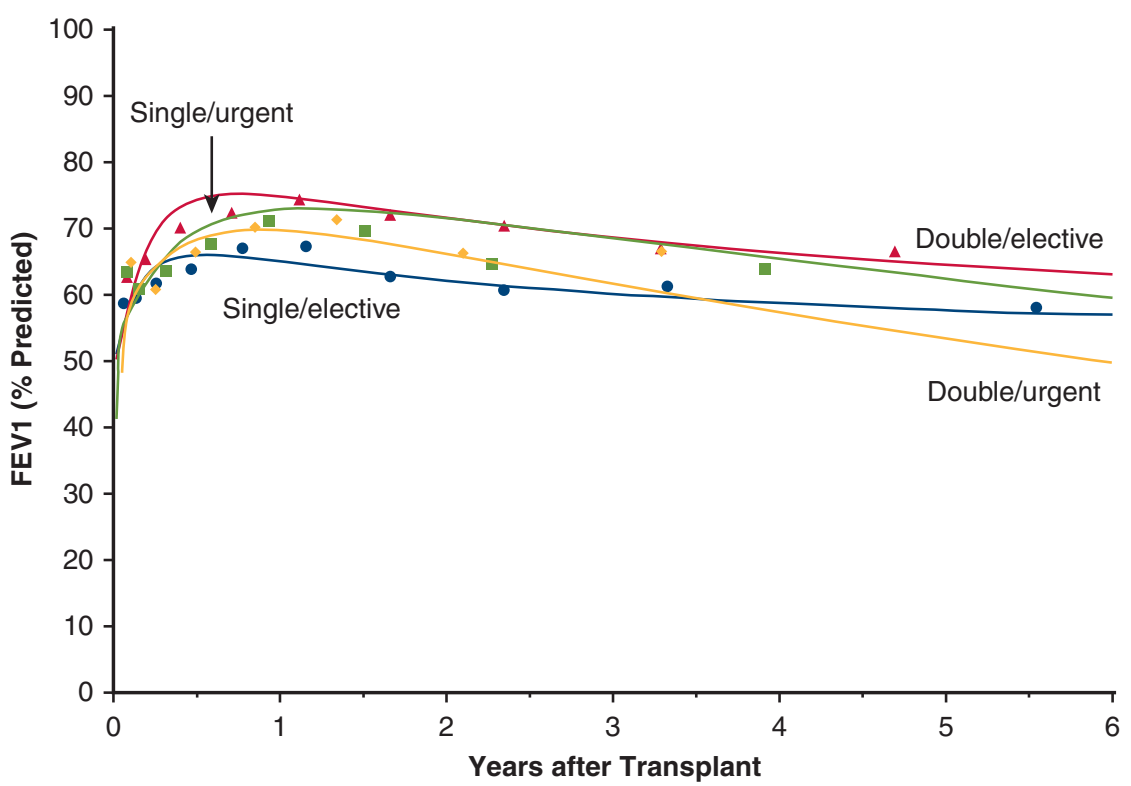

FIGURE 4. Temporal trend of allograft function measured by FEV1 (percent of predicted) after transplant in urgently listed and electively listed patients, both stratified by double- versus single-lung transplantation. Symbols represent average values without accounting for repeated measures as a crude verification of longitudinal parametric mixed-effect modeling results with patient as a random effect. Number of patients remaining at risk and number of FEV1 records at and beyond selected time points are shown graphically in Figure E2. FEV1, Forced expiratory volume in 1 second.

function to those electively listed. Urgently listed transplant patients with worse liver function, as evidenced by a higher international normalized ratio, were more likely to die early after transplant, and those with lower albumin and higher bilirubin were more likely to die later after transplant.

\section{Clinical Implications}

In a continuing effort to maximize the longevity and function of transplanted organs, centers aim to list candidates who carry low risk of mortality and nonpulmonary complications. Development and use of the LAS have allowed programs in the United States to rank candidates based on pulmonary-related risk factors. However, the LAS does not fully capture risk of mortality after transplantation for sick patients at the higher extremes of the LAS. ${ }^{15,16}$ Li and colleagues ${ }^{15}$ showed a ceiling effect in survival for patients with a LAS higher than 70 and recommended establishing an upper limit.

Patients with acute fulminant pulmonary failure require transplantation and are increasingly referred to transplant centers for evaluation. These are typically high-LAS patients, who get priority for organs based on their score. Yet there is a paucity of data on short- and long-term outcomes in this group. European centers have reported variable survival outcomes in urgently transplanted patients. ${ }^{17-21}$ However, it is unclear from these reports if patients were listed and then deteriorated and required urgent transplantation, or if they truly presented acutely and were listed and urgently transplanted.
In our experience, one third of urgently listed patients did not receive a transplant. Most were severely ill with a high LAS and died before transplant; a few improved and were delisted. The two thirds of urgently listed patients who underwent transplant were younger than their electively listed counterparts and had worse pulmonary disease with higher LAS. Managing these patients can require extensive resources, as suggested by more patients on mechanical ventilation and ECMO pretransplant. This is consistent with previous reports documenting increasing health care costs as LAS increases. ${ }^{22,23}$ However, despite this, urgently listed transplant patients have short-term mortality and long-term survival similar to that of electively listed patients. In our series, survival of these urgently listed patients was superior to what has been reported for patients with idiopathic pulmonary fibrosis exacerbation ${ }^{5}$ or acute respiratory distress syndrome. ${ }^{24}$ The $13 \%$ in-hospital mortality was especially encouraging for such a complex and high-risk group of patients, because they are at the greatest risk of mortality in the early post-transplant period. Furthermore, 5-year survival for both urgently listed and electively listed transplant patients in our series was on par with reported 5-year survival in other lung transplant reports.

\section{Should We Continue to Accept, List, and Transplant Such Patients?}

Transplant centers and teams must consider their own results and willingness to devote resources before accepting such complex patients. These cases can strain health care 
resources and personnel. There is increasing evidence that mortality after thoracic surgery, including lung transplant, partly depends on a program's ability to rescue patients from complications. ${ }^{25}$ In addition, because a large proportion of urgently listed patients will die before transplant, the decision to list such patients should be made judiciously, yet expeditiously. Not all programs should urgently list patients in acute respiratory failure. It is difficult to imagine how the current LAS and organ allocation system in general can accommodate urgent requests to find appropriate organs in a relatively short time. To address this issue, Scandinavian transplant centers use a system that is somewhat similar to obtaining an "exception" in the United States. ${ }^{18}$ Unfortunately, the national data on urgent listing are sparse. However, one could argue that higher-volume centers with active ECMO and ex-vivo lung perfusion programs should evaluate these higher-risk patients. ${ }^{26}$ As such a transplant institution, we found that older patients, those with worse liver function, and outside hospital transfers were most likely to die after urgent listing before transplant. To mitigate some of the risk, our program accepts such patients in transfer with the clear understanding that they will be thoroughly reevaluated to determine candidacy. When evaluating these patients, we have repeatedly found that although objective physiologic findings may be similar to what was reported from the referring institution, psychosocial factors, including social support structure, change over time and require in-depth evaluation.

However, well-selected urgently evaluated patients may have greater physiologic reserve at the time of listing compared with patients with chronic lung disease who deteriorate slowly over time. Although urgently listed transplant patients have higher LAS, which could be due to their nonambulatory status after fulminant respiratory failure, they otherwise are able to recuperate from their acute illness surprisingly well.

\section{How Can We Improve Patient Selection?}

We did not find LAS to be a significant predictor of competing events after urgent listing or mortality after urgently listed transplantation. This could be due to the majority of these patients having high LAS scores $(>40)$ and the inability of the LAS to capture high-risk features beyond a certain point. Further investigation of nonpulmonary risk factors such as frailty, sarcopenia, malnutrition, and other organ-system dysfunction may better stratify risk. ${ }^{27,28}$ Psychosocial factors, such as history of noncompliance, addiction to narcotics, ${ }^{29}$ and lack of social support, ${ }^{30}$ have been known to negatively affect outcomes and factor into the decision of whether to list a patient for transplant. Therefore, LAS by itself may be insufficient to risk stratify this group.

We propose evaluating these patients on a case-by-case basis. Our program takes an aggressive approach toward evaluation and listing. Patients are urgently evaluated by transplant medical and surgical teams, social workers, and palliative medicine staff, among other ancillary groups. Bedridden patients, including those on mechanical ventilation, may be frail and debilitated. Therefore, early institution of extracorporeal support, typically in the form of veno-venous ECMO, is used as a "bridge to decision." If patients are unable to rehabilitate, they are not considered transplant candidates. If they show physiologic improvement, they are continued on ECMO as "bridge to transplantation." This approach has allowed us to improve selection in this rather heterogeneous group. We recommend early involvement of the transplant team so that multidisciplinary evaluation can be performed and patients without absolute contraindications may be appropriately identified.

\section{Limitations and Strengths}

This is a retrospective description of an extremely heterogeneous group of patients. Although most of the data originated from our center, some workup may have been performed before transfer. Unfortunately, there was no way of identifying patients who presented to our institution with acute respiratory failure but were not listed for transplant. Our comparison groups of urgently listed and electively listed transplant patients are inherently different, violating the exchangeability assumption underlying propensity score methodology. Rather, urgent listing can be considered a "natural experiment" for which balancing scores are considered statistically appropriate. ${ }^{31}$

Despite these limitations, this study is one of the largest focusing on urgently listed transplant patients. In addition, this appears to be the only description of clinical characteristics of patients who were urgently listed but not transplanted.

\section{CONCLUSIONS}

Urgent listing more often than not leads to lung transplant. Although urgently listed patients are sicker overall, after transplant they had similar perioperative morbidity and mortality, time-related survival, and longitudinal allograft function. Appropriate patient selection and aggressive supportive care allow urgently listed lung transplant patients to achieve similar outcomes. Further investigation into risk factors not captured by the LAS should be undertaken to better risk stratify these patients at the extreme end of acute respiratory failure.

\section{Webcast}

You can watch a Webcast of this AATS meeting presentation by going to: https://aats.blob.core.windows.net/media/ 19\%20AM/Sunday_May5/201DF/201DF/S63\%20-\%20 Lung $\% 20$ transplantation $\% 20$ - $\% 20$ protecting $\% 20$ the $\%$ 20graft/S63_4_webcast_051232663.mp4. 


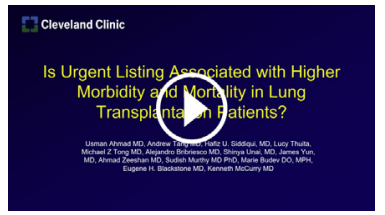

\section{Conflict of Interest Statement}

The authors reported no conflicts of interest.

The Journal policy requires editors and reviewers to disclose conflicts of interest and to decline handling or reviewing manuscripts for which they may have a conflict of interest. The editors and reviewers of this article have no conflicts of interest.

\section{Collaborators}

\section{Cleveland Clinic Lung Transplant Center}

Michael Z. Tong, MD (Department of Thoracic and Cardiovascular Surgery, Department of Inflammation and Immunity); Alejandro Bribriesco, MD (Department of Thoracic and Cardiovascular Surgery, Department of Inflammation and Immunity); Douglas R. Johnston, MD (Department of Thoracic and Cardiovascular Surgery); Shinya Unai, MD (Department of Thoracic and Cardiovascular Surgery, Department of Inflammation and Immunity); James Yun, MD (Department of Thoracic and Cardiovascular Surgery, Department of Inflammation and Immunity); Ahmad Zeeshan, MD (Department of Thoracic and Cardiovascular Surgery, Department of Inflammation and Immunity); Sudish C. Murthy, MD, PhD (Department of Thoracic and Cardiovascular Surgery); and Marie Budev, DO, MPH (Department of Pulmonary Medicine, Department of Inflammation and Immunity).

\section{References}

1. Valapour M, Lehr CJ, Skeans MA, Smith JM, Uccellini K, Lehman R, et al. OPTN/SRTR 2017 annual data report: lung. Am J Transplant. 2019;19(suppl 2):404-84.

2. Orens JB, Estenne M, Arcasoy S, Conte JV, Corris P, Egan JJ, et al. International guidelines for the selection of lung transplant candidates: 2006 update-a consensus report from the pulmonary scientific council of the International Society for Heart and Lung Transplantation. J Heart Lung Transplant. 2006;25: 745-55.

3. Weill D, Benden C, Corris PA, Dark JH, Davis RD, Keshavjee S, et al. A consensus document for the selection of lung transplant candidates: 2014 —an update from the pulmonary transplantation council of the International Society for Heart and Lung Transplantation. J Heart Lung Transplant. 2015;34:1-15.

4. Gottlieb J, Warnecke G, Hadem J, Dierich M, Wiesner O, Fuhner T, et al. Outcome of critically ill lung transplant candidates on invasive respiratory support. Intensive Care Med. 2012;38:968-75.

5. George TJ, Beaty CA, Kilic A, Shah PD, Merlo CA, Shah AS. Outcomes and temporal trends among high-risk patients after lung transplantation in the United States. J Heart Lung Transplant. 2012;31:1182-91.

6. Mason DP, Thuita L, Nowicki ER, Murthy SC, Pettersson GB, Blackstone EH. Should lung transplantation be performed for patients on mechanical respiratory support? The US experience. J Thorac Cardiovasc Surg. 2010;139:765-73.

7. Dotan Y, Vaidy A, Shapiro WB, Zhao H, Dass C, Toyoda Y, et al. Effect of acute exacerbation of idiopathic pulmonary fibrosis on lung transplantation outcome. Chest. 2018;154:818-26.

8. Doi A, Lee G, Snell G, Bloch M, Summerhayes R, Marasco S. Lung transplantation as rescue therapy in patients too sick to be discharged from acute care. Transplant Proc. 2014;46:256-9.
9. Andersen PK, Borgan O, Gill RD. Statistical Models Based on Counting Processes. Chapter 4: Nonparametric estimation. New York: Springer-Verlag; 1993:176-331.

10. Rajeswaran J, Blackstone EH. Identifying risk factors: challenges of separating signal from noise. J Thorac Cardiovasc Surg. 2017;153:1136-8.

11. Li L, Greene T. A weighting analogue to pair matching in propensity score anal ysis. Int J Biostat. 2013;9:215-34.

12. Blackstone EH, Naftel DC, Turner ME Jr. The decomposition of time-varying hazard into phases, each incorporating a separate stream of concomitant information. J Am Stat Assoc. 1986;81:615-24.

13. Rajeswaran J, Blackstone EH. A multiphase non-linear mixed effects model: an application to spirometry after lung transplantation. Stat Methods Med Res. 2017; 26:21-42.

14. Rubin DB. Multiple Imputation for Non-Response in Surveys. New York: Wiley; 1987.

15. Li SS, Miller R, Tumin D, Stewart WCL, Tobias JD, Hayes D Jr. Lung allocation score thresholds prioritize survival after lung transplantation. Chest. 2019;156: 64-70.

16. Hayanga JA, Lira A, Vlahu T, Yang J, Aboagye JK, Hayanga HK, et al. Lung transplantation in patients with high lung allocation scores in the US: evidence for the need to evaluate score specific outcomes. J Transplant. 2015;2015: 836751 .

17. Roux A, Beaumont-Azuar L, Hamid AM, De Miranda S, Grenet D, Briend G et al. High emergency lung transplantation: dramatic decrease of waiting lis death rate without relevant higher post-transplant mortality. Transpl Int. 2015; 28:1092-101.

18. Auraen H, Schultz HHL, Hammainen P, Riise GC, Larsson H, Hansson L, et al Urgent lung allocation system in the Scandiatransplant countries. J Heart Lung Transplant. 2018;37:1403-9.

19. Schiavon M, Faggi G, Di Gregorio G, Calabrese F, Lunardi F, Marulli G, et al Single-center experience in urgent lung transplantation program in a country with a shortage of donors: does the end justify the means? Clin Transplant. 2017;31:e13129.

20. Boffini M, Venuta F, Rea F, Colledan M, Santambrogio L, D'Armini AM, et al Urgent lung transplant programme in Italy: analysis of the first 14 months. Interact Cardiovasc Thorac Surg. 2014;19:795-800.

21. Orsini B, Sage E, Olland A, Cochet E, Tabutin M, Thumerel M, et al. High-emergency waiting list for lung transplantation: early results of a nation-based study Eur J Cardiothorac Surg. 2014;46:e41-7.

22. Keller CA, Gonwa TA, White LJ, Rucci ME, Visscher SL, Kennedy CC, et al Utilization and cost analysis of lung transplantation and survival after 10 years of adapting the lung allocation score. Transplantation. 2019;103:638-46.

23. Arnaoutakis GJ, Allen JG, Merlo CA, Sullivan BE, Baumgartner WA, Conte JV et al. Impact of the lung allocation score on resource utilization after lung transplantation in the United States. J Heart Lung Transplant. 2011;30:14-21.

24. Chang Y, Lee SO, Shim TS, Choi SH, Kim HR, Kim YH, et al. Lung transplantation as a therapeutic option in acute respiratory distress syndrome. Transplantation. 2018;102:829-37.

25. Farjah F. Failure-to-rescue in thoracic surgery. Thorac Surg Clin. 2017;27: 257-66.

26. Beller JP, Hawkins RB, Mehaffey JH, Chancellor WZ, Teaster R, Walters DM et al. Poor performance flagging is associated with fewer transplantations at centers flagged multiple times. Ann Thorac Surg. 2019;107:1678-82.

27. Hsu J, Krishnan A, Lin CT, Shah PD, Broderick SR, Higgins RSD, et al. Sarcopenia of the psoas muscles is associated with poor outcomes following lung transplantation. Ann Thorac Surg. 2019;107:1082-8.

28. Layton AM, Armstrong HF, Baldwin MR, Podolanczuk AJ, Pieszchata NM, Singer JP, et al. Frailty and maximal exercise capacity in adult lung transplant candidates. Respir Med. 2017;131:70-6.

29. Drees D, Tumin D, Miller R, Kirkby S, Bhalla T, Tobias JD, et al. Chronic opioid use and clinical outcomes in lung transplant recipients: a single-center cohort study. Clin Respir J. 2018;12:2446-53.

30. Smith PJ, Snyder LD, Palmer SM, Hoffman BM, Stonerock GL, Ingle KK, et al. Depression, social support, and clinical outcomes following lung transplantation: a single-center cohort study. Transpl Int. 2018;31:495-502.

31. Rosenbaum PR, Rubin DB. Reducing bias in observational studies using subclassification on the propensity score. J Am Stat Assoc. 1984;79:516-24.

Key Words: lung transplantation, urgent, forced expiratory volume in 1 second, outcomes 


\section{Discussion}

\section{Presenter: Dr Usman Ahmad}

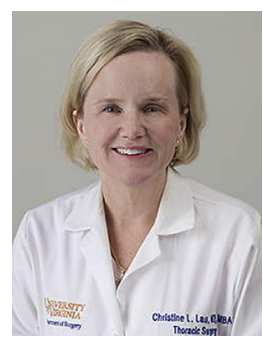

Dr Christine Lau (Baltimore, $M d$ ). I'd

like to congratulate you and your colleagues on an outstanding presentation. And I appreciate you giving me your paper and your slides to review ahead of time. This is obviously an important and timely topic, given the changing landscape of lung transplantation. You and your colleagues are clearly on the forefront of this, given you have a decade of experience already.

I can tell you, at The University of Virginia we're still grappling with how to accommodate and work up these urgent listings. I do have a few questions. Do you think that more centers should offer urgent listing of transplants, or do you feel that centers should be identified that can handle these high-resource patients, and if so, how do you see this playing out?

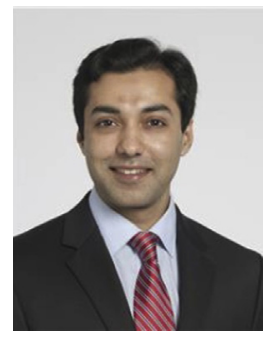

Dr Usman Ahmad (Cleveland, Ohio). Great question! And I'm going to refer back to a paper written by Dr Lau and colleagues that talks about how the Centers for Medicare \& Medicaid Services evaluates and penalizes transplant centers with high center mortality! The bottom line is that it comes down to the center's outcomes, and every center has to look at its own outcomes and decide what risk it is willing to take. It's hard to say that we're going to come up with the generalizable statement based on these patients to take care of these patients.

Dr Lau. Another thing that we found was as we did these urgent workups and listed these patients they would continue to deteriorate-I know you've alluded to it-it's difficult to tell which ones to list and which ones to keep listed, but when you urgently list them do you have a decision point, for instance, you say, okay, this patient will not go on extracorporeal membrane oxygenation (ECMO). This patient will go on ECMO. Do you guys have very clear identified stopping points once you urgently list somebody?

Dr Ahmad. That's a great question. I'd probably be a millionaire if I could quantify the surgeon's eyeball test, but I can't. That's essentially what it comes down to, but in terms of the hard sort of stop points and checkpoints and putting a patient on ECMO or not, we typically stick to patients 55 years and younger as a programmatic guideline. I don't think there's a whole lot of data behind that, and we've seen very debilitated 20 -year-olds and very healthy $60+$-year-olds who have gone through this process with extracorporeal support and have had reasonable outcomes.

But those are the general numbers, of course. We would typically not initiate somebody on ECMO if they're 55 years or older or if they're extremely debilitated. Now, what I will say is that we have used ECMO as a bridge to decision in such sick patients. If we think they have the potential to rehabilitate, we would not list or refuse them upfront. Rather, we put them on ECMO, rehabilitate them, and then make a decision whether to proceed with the transplant listing or to withdraw support.

Dr Lau. Thank you.

Dr Ahmad. Thank you.

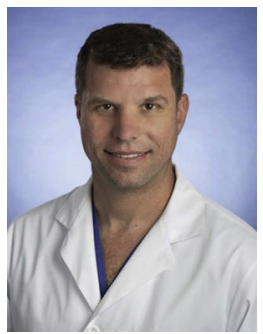

Dr Marcelo Cypel (Toronto, Ontario, Canada). Very nice presentation. So I just have a couple of questions. One of them is of these 200 patients, urgent listing, were some of these patients known or added to the transfer program and they just were not listed but they had a rapid deterioration and then were eventually listed? My other question is: What was the wait time for these people waiting for transplants? Have you used more extended-criteria donors for this population to get them access early on so they have that data?

Dr Ahmad. To answer your first question, some of them were listed to our center, although the vast majority were either transferred from other medical intensive care units when they were in new-onset respiratory failure or from other transplant centers that were unwilling to list them. Second, the wait time from listing to transplant, as I showed, is about 20 days in these urgent patients. Regarding the wait time from hospital admission to listing, I don't have that. That's a good question.

Dr Cypel. Finally, how do you manage the patients who come to your center fully sedated on a ventilator and haven't had a discussion about lung transplant?

Dr Ahmad. That's a great question, Marcelo. These are challenges we struggle with every time in every single one of these patients, and some of the factors that we struggle with post-transplant are not really physiologic. They could be more psychosocial. Some patients may never have wanted a transplant; these are some of the issues we all struggle with, and using ECMO as a bridge to decision has really helped us get through some of these difficult situations.

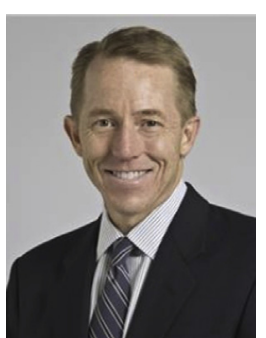

Dr Kenneth R. McCurry (Cleveland, Ohio). I'll just extrapolate on that. We've probably done about maybe 10 or so transplants, I would say, in the last 18 months along those lines, Marcelo. Patients that came to us either on ECMO or on a ventilator, sedated and paralyzed, that we rehabbed and ultimately got to a point where we felt we could transplant.

Dr Lau. One more question and then one comment. The one patient who died in our study was an urgently listed pa- 
tient, and we found that he had cancer, and we took his lungs, both lungs, and also in the lymph nodes at the time of explant. What do you do? Do you complete the entire workup for these patients? Obviously, we had a computed tomography scan, it was unexpected, but in general do you get colonoscopies? How do you do all that? Urgently?

Dr Ahmad. We've had that situation before, too, where unexpected malignancy was found and, in the explants, but these patients were not in the urgent group. So, in terms of the workup, getting complete testing can be challenging. As you know, some of it depends on what physiologic shape or form the patient is in. When patients are intubated or require high oxygen supplementation, such as non-rebreather masks, getting gastrointestinal studies is out of question. We end up relying on detailed history and imaging studies. We do measure prostate-specific antigen level routinely.

But that's about it. Some of the bigger and important things that can get skipped when a patient, let's say, is on mechanical ventilation or ECMO, are the psychosocial evaluation, the oncologic evaluation, the family/social support, and so forth. Despite thorough multidisciplinary evaluation, and when time is of the essence, family and social structure rally around and agree to support, but it's really after the transplant when things start to change, and there are cases where we have struggled with these unpredictable issues.

Dr Lau. How do you get everybody on the same page? So, you have a transplant surgeon at the meeting, and they agree to do this urgent patient, and then tag, you're it. It's your partner doing the transplant. Everybody buy into that?

Dr Ahmad. We're fortunate that we have a very tightknit group that after extensive multidisciplinary evaluations, including gastrointestinal workup, oncologic workup, and so on, makes a combined decision. Some urgent decisions are made on e-mail exchanges, but typically with the whole group contributing to the decision-making. We're also somewhat unique in that we have both thoracic and cardiac surgeons in the multidisciplinary group, and some of our pulmonologists and thoracic surgeons are also part of the thoracic oncology teams, which makes some of these complex selections easier.

Dr McCurry. I would say that the default position in our program, certainly for the last decade, has been to be aggressive, and that's the way we see it. We believe in giving patients an opportunity at survival and that's the way we approach things. Thank you very much.

Dr Ahmad. Thank you very much. 


\section{APPENDIX E1: VARIABLES CONSIDERED AT TIME OF LISTING FOR URGENTLY LISTED GROUP}

Demographics: age, sex, race, height, weight, weight/ height ratio, body surface area, body mass index

Blood type: A, AB, B, O

Diagnosis: cystic fibrosis, obstructive lung disease, pulmonary vascular disease, restrictive lung disease

Diagnosis (granular): cystic fibrosis or bronchiectasis, chronic obstructive pulmonary disease/emphysema/alpha1 antitrypsin deficiency, idiopathic pulmonary fibrosis, sarcoidosis

Medical history: chronic obstructive pulmonary disease, diabetes, gastroesophageal reflux disease, hypertension, history of smoking, thoracotomy, tracheostomy, transfusion

Hospitalization: transfer from outside facility, Karnofsky score

Life support: ventilator, extracorporeal membrane oxygenation, on inotropes

Nutrition: albumin, total protein

Renal: blood urea nitrogen, creatinine, creatinine clearance, glomerular filtration rate

Liver: bilirubin, international normalized ratio, model for end-stage renal disease (MELD) score

Hematology: hematocrit, hemoglobin, platelets

Respiratory: forced expiratory volume in 1 second (percent predicted), forced vital capacity (percent predicted)

Blood pressure: systolic, diastolic, mean

Hemodynamics: pulmonary artery pressure (systolic, diastolic, mean), wedge pressure, right ventricular pressure (systolic, diastolic), left ventricular pressure, ejection fraction

Lung allocation score: lung allocation score at listing

Serology/antibodies: Epstein-Barr virus IgG, cytomegalovirus

Interval: date of listing

\section{APPENDIX E2: BASELINE VARIABLES CONSIDERED IN MULTIVARIABLE ANALYSES OF LUNG TRANSPLANT RECIPIENTS AND DONORS \\ Recipient}

Demographics: age, ${ }^{*}$ sex, ${ }^{*}$ race, ${ }^{*}$ height, weight, weight/ height ratio, body surface area, body mass index*

Blood type: A,* AB, B, O*

Antigen/antibodies: Epstein-Barr virus IgG, cytomegalovirus; panel reactive antibodies

Diagnosis: cystic fibrosis, obstructive lung disease, * pulmonary vascular disease, restrictive lung disease

Diagnosis (granular): cystic fibrosis or bronchiectasis, chronic obstructive pulmonary disease/emphysema/alpha-1 antitrypsin deficiency, idiopathic pulmonary fibrosis, sarcoidosis

Medical history: chronic obstructive pulmonary disease, diabetes, ${ }^{*}$ gastroesophageal reflux disease, hypertension,* history of smoking,* thoracotomy, tracheostomy,* transfusion

Hospitalization: transfer from outside facility, in intensive care unit,* Karnofsky score

Life support: ventilator,* extracorporeal membrane oxygenation,* intubated at Cleveland Clinic, intubated at outside hospital

Nutrition: albumin,* total protein

Renal: blood urea nitrogen,* creatinine, creatinine clearance, glomerular filtration rate*

Liver: bilirubin,* international normalized ratio, model for end-stage liver disease (MELD) score*

Hematology: hematocrit, hemoglobin, platelets

Respiratory: forced expiratory volume in 1 second (percent predicted), ${ }^{*}$ forced vital capacity (percent predicted)

Blood pressure: systolic, diastolic, mean

Hemodynamics/cath/echo: cardiac output, pulmonary artery pressure (systolic, diastolic, mean*), ejection fraction, right ventricular pressure (diastolic \& systolic), wedge, right atrial mean pressure, right ventricular dilatation, right ventricular dysfunction, tricuspid regurgitation, mitral regurgitation, left atrial enlargement, left ventricular dilatation, left ventricular dysfunction

Lung allocation score: lung allocation score at transplant*

Intervals: preoperative length of hospital stay, date of transplant*

Surgical: ischemic time, double/single lung transplant,* coronary artery bypass grafting

\section{Donor}

Demographics: age,* sex,* race, height, weight, weight/ height ratio, body surface area, body mass index

Blood type: A, AB, B, O

Other: blood urea nitrogen, creatinine, Epstein-Barr virus, immunoglobulin $\mathrm{G}$, alcohol use, antihypertensive medication, clinical infection, history of smoking,* cancer, recreational drugs, cause of death (anoxia, stroke, trauma)

Lab values: blood urea nitrogen, creatinine

\section{Recipient and Donor}

Sex mismatch, race mismatch,* weight ratio

Note: Asterisks denote variables used in weighted propensity matching. 


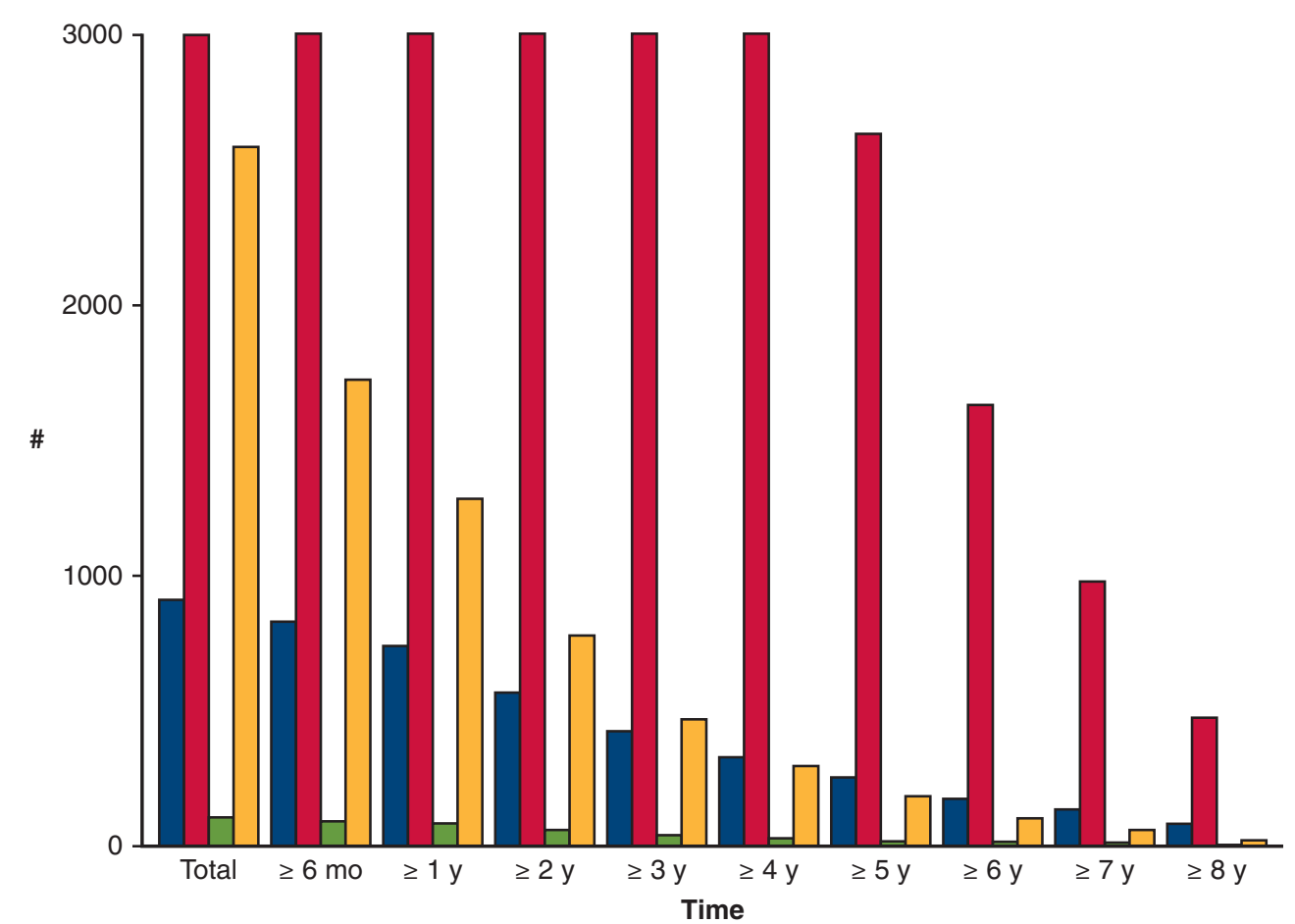

Number:

$\begin{array}{lcccccccccc}\square \text { Patients-ULT } & 108 & 97 & 85 & 62 & 43 & 32 & 21 & 14 & 9 & 5 \\ \square \text { FEV1 Records-ULT } & 2583 & 1724 & 1284 & 782 & 468 & 300 & 186 & 107 & 62 & 24 \\ \square \text { Patients-ELT } & 910 & 830 & 740 & 570 & 429 & 332 & 256 & 177 & 137 & 86 \\ \square \text { FEV1 Records-ELT } & 26,179 & 17,959 & 14,220 & 9375 & 6184 & 4168 & 2632 & 1632 & 980 & 476\end{array}$

FIGURE E1. Number of ULT and ELT patients and number of FEV1 (percent predicted) records available at and beyond various time points following lung transplant. $U L T$, Urgently listed and transplanted; FEV1, forced expiratory volume in 1 second; ELT, electively listed and transplanted. 


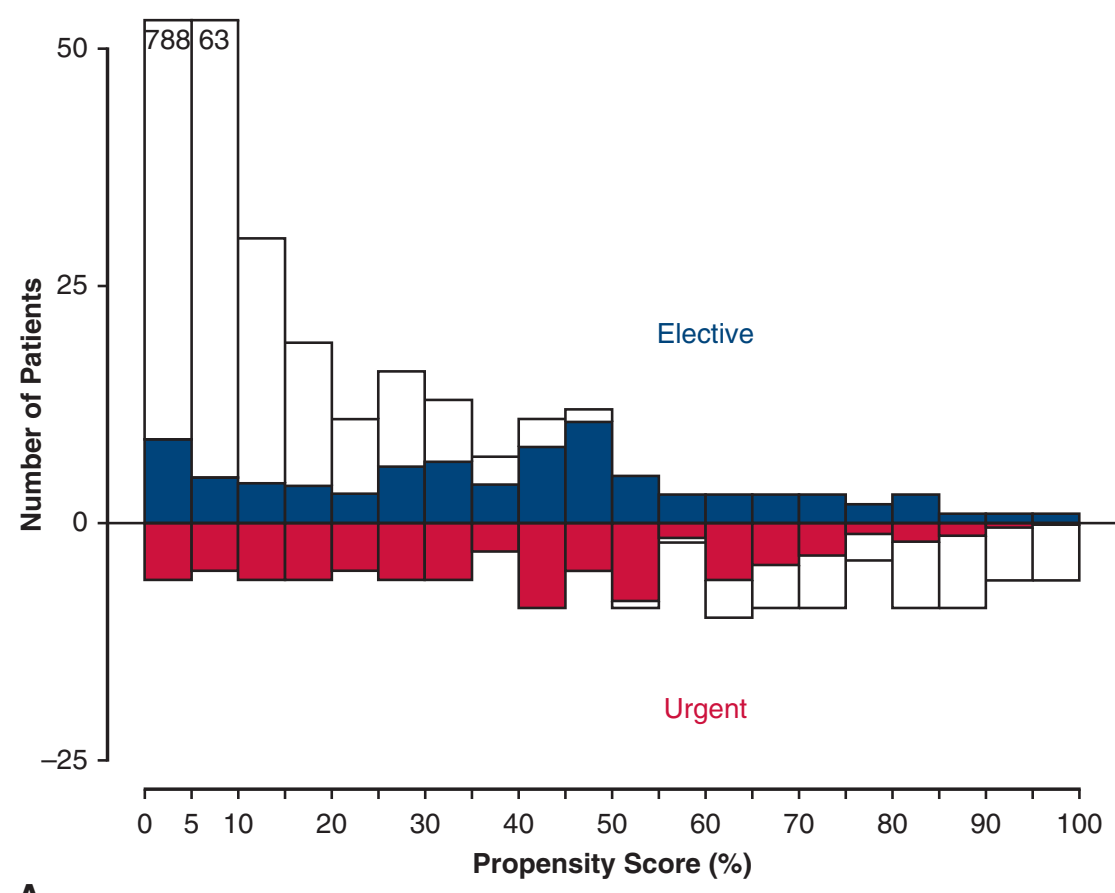

A

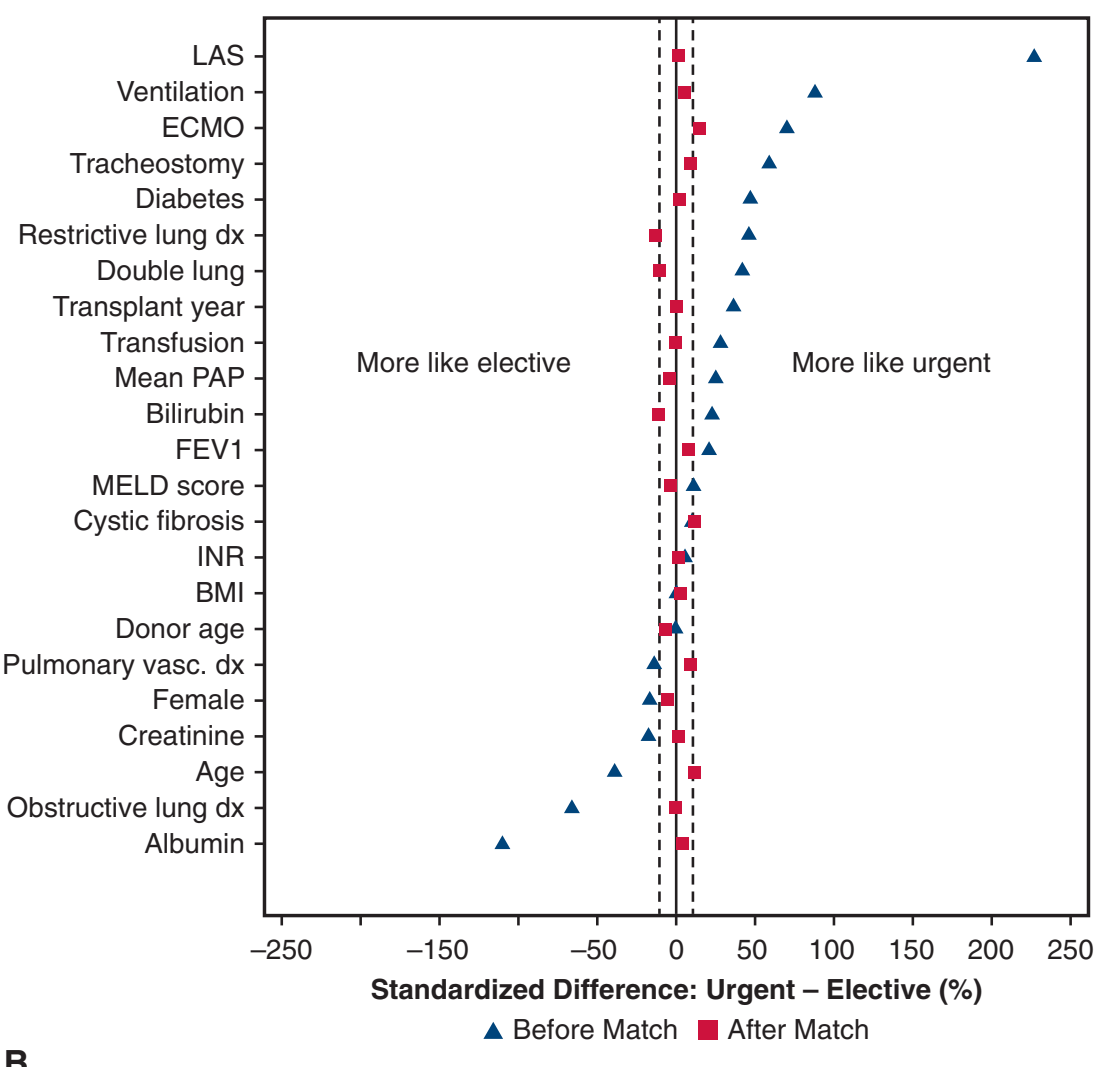

FIGURE E2. Quality of weighted balancing score matching of urgently listed and electively listed lung transplant patients. A, Mirrored histogram of distribution of weighted balancing scores between groups. Shaded areas indicate matched patient pairs, showing that they cover the complete spectrum of cases. B, Standardized differences of selected variables before and after matching. Vertical dashed lines at $-10 \%$ and $+10 \%$ indicate boundaries of desirable matching. Blue triangles represent standardized differences before weighted propensity score-based matching, with positive values indicating a variable is more common in the urgently listed group and negative values indicating variables more characteristic of patients in the electively listed group. Red squares represent values after matching. $L A S$, Lung allocation score; $E C M O$, extracorporeal membrane oxygenation; $d x$, disease; $F E V 1(\%)$, forced expiratory volume in 1 second (percent of predicted); MELD, model for end-stage liver disease; INR, international normalized ratio; BMI, body mass index; vasc., vascular. 


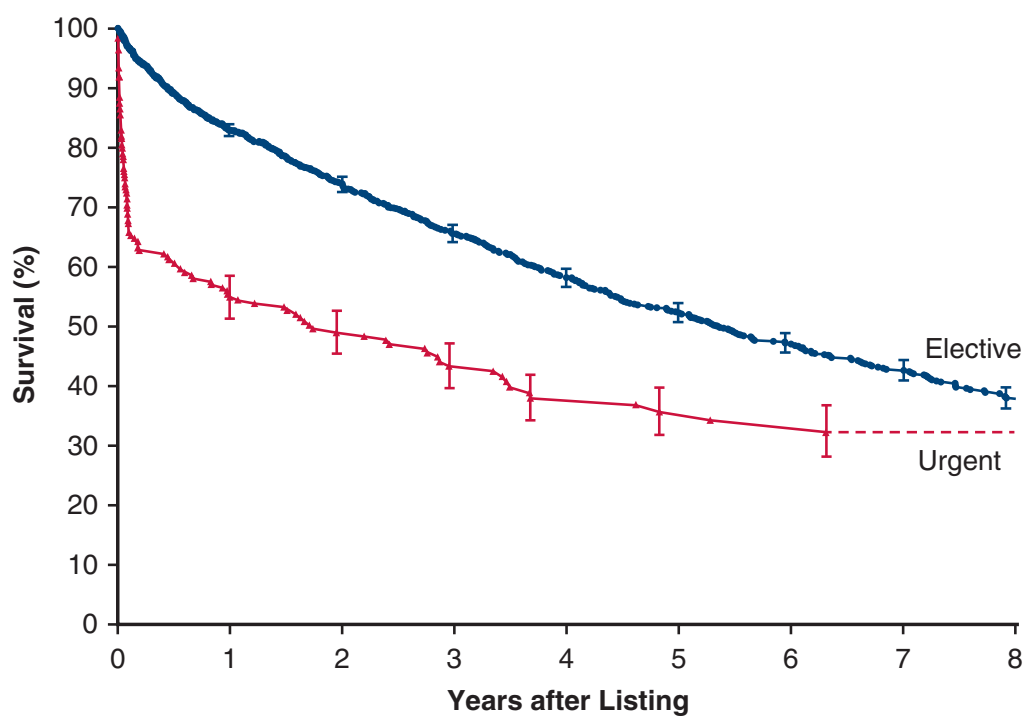

Patients at risk

$\begin{array}{rccccccccc}\text { Urgent } & 201 & 105 & 77 & 51 & 34 & 26 & 17 & 16 & 16 \\ \text { Elective } & 1423 & 1056 & 824 & 636 & 489 & 397 & 300 & 226 & 157\end{array}$

FIGURE E3. Death at any time after listing, including post-transplant deaths, among urgently listed (red symbols and line) and electively listed (blue symbols and line) patients. Vertical bars are $68 \%$ confidence limits, equivalent to \pm 1 standard error. Numbers below horizontal axis are patients still followed beyond that time point.

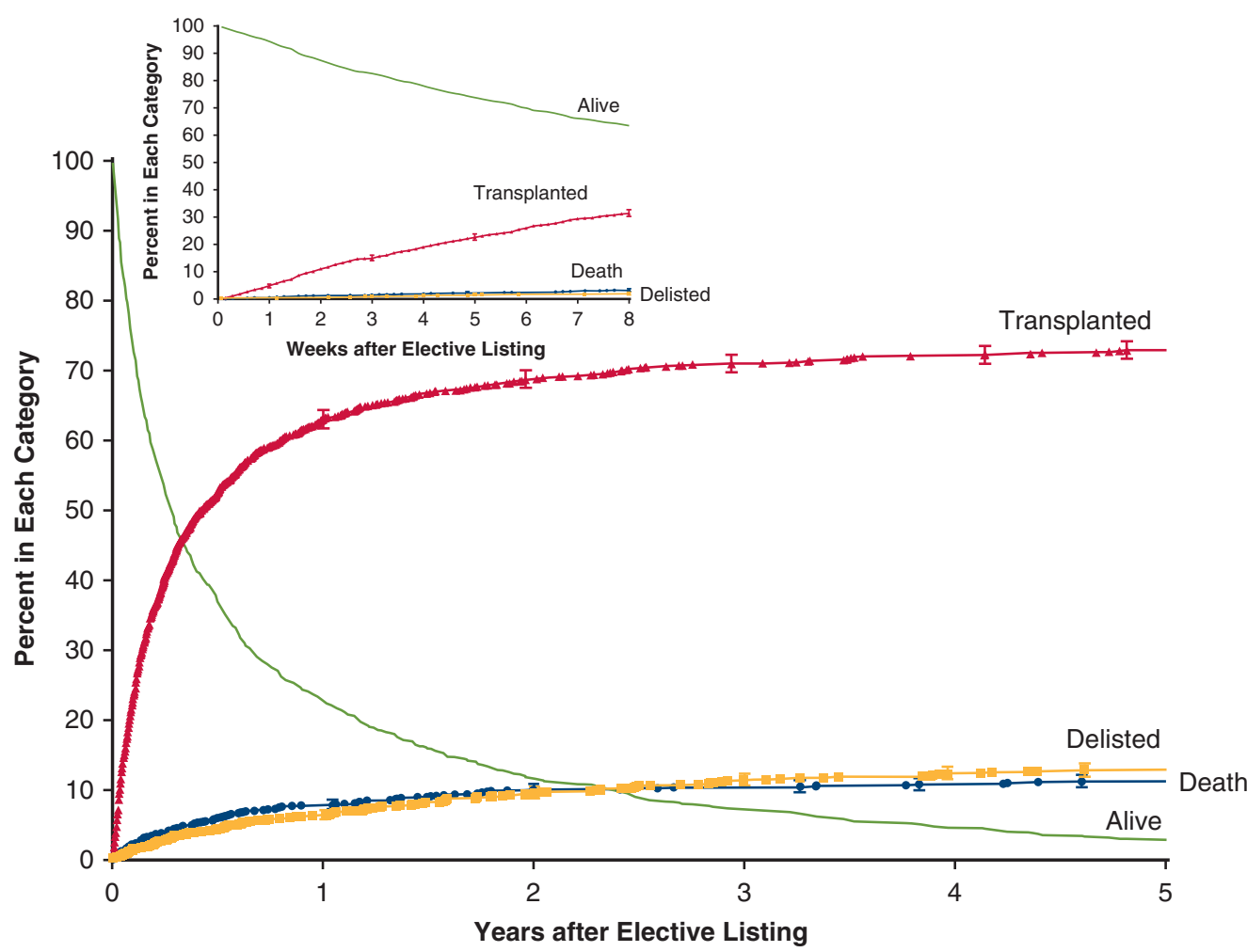

Patients at risk

\# patients 1423

298

140

81

47

29

FIGURE E4. Cumulative incidence of transplantation and death before transplantation, after elective listing. Inset: Cumulative incidence over period of 8 weeks after elective listing. Format is as in Figure 2. 


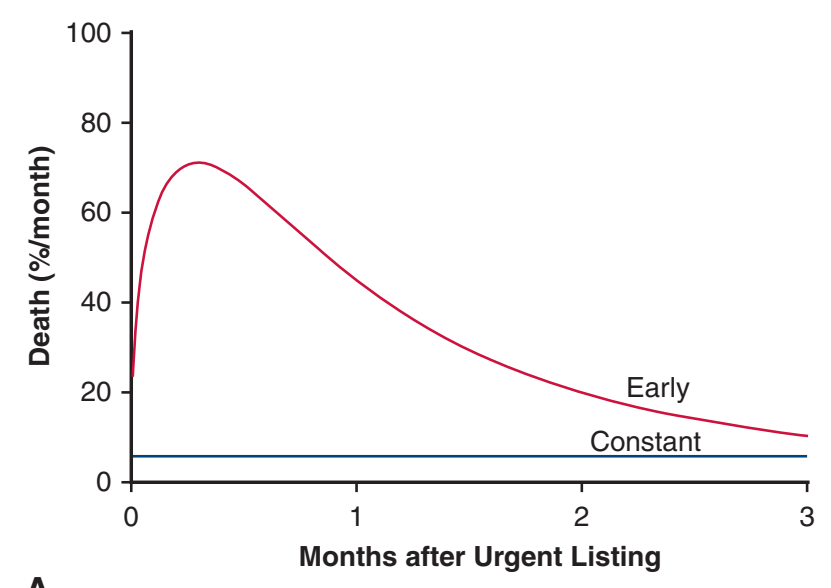

A

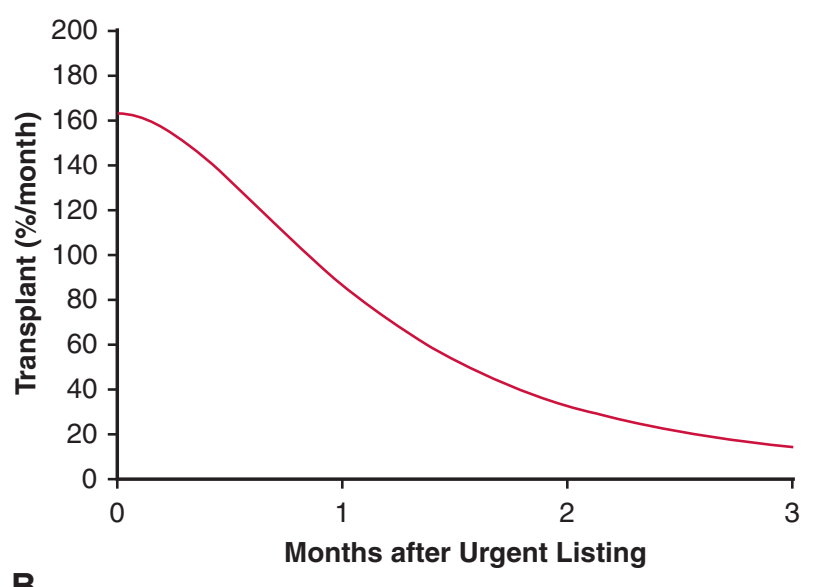

FIGURE E5. Instantaneous risk of death after urgent listing for transplantation. A, Two hazard phases for death were resolved, early and constant. Total hazard is the sum of these phases at each point in time. B, A single phase of hazard for transplant was resolved.

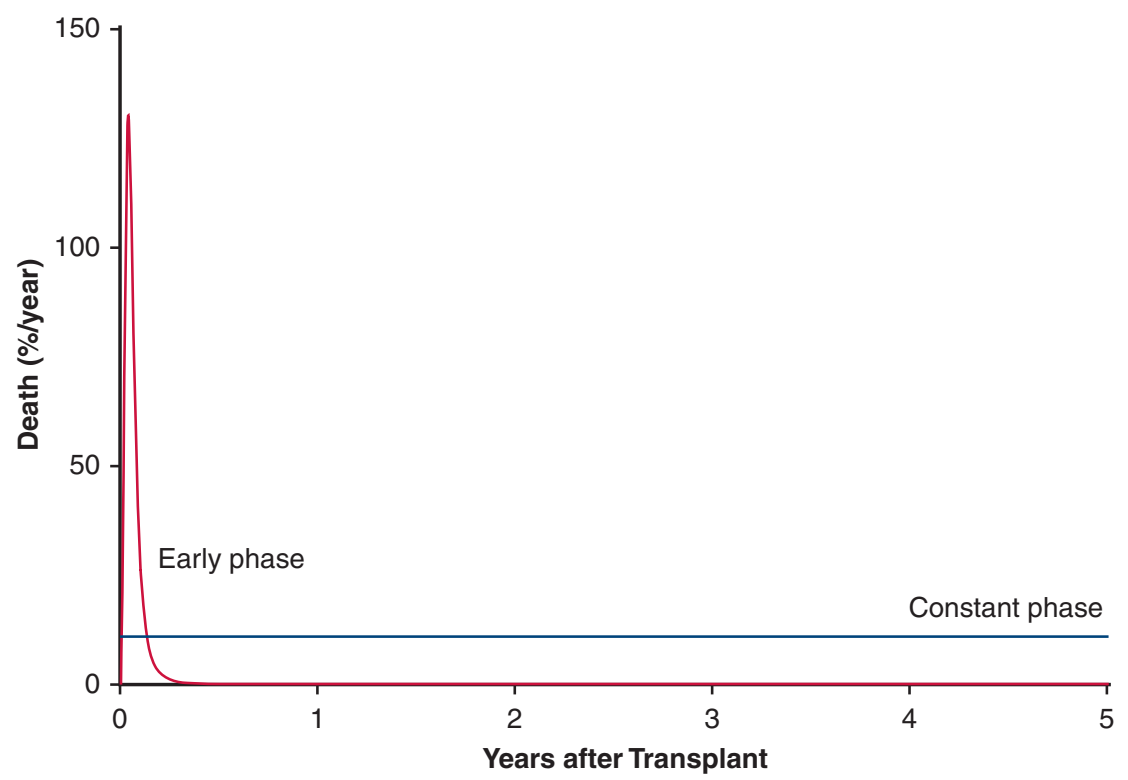

FIGURE E6. Phases of hazard comprising instantaneous risk of death after transplant for urgently listed patients. The early hazard phase (red line) is brief and merges with the constant hazard over time. 


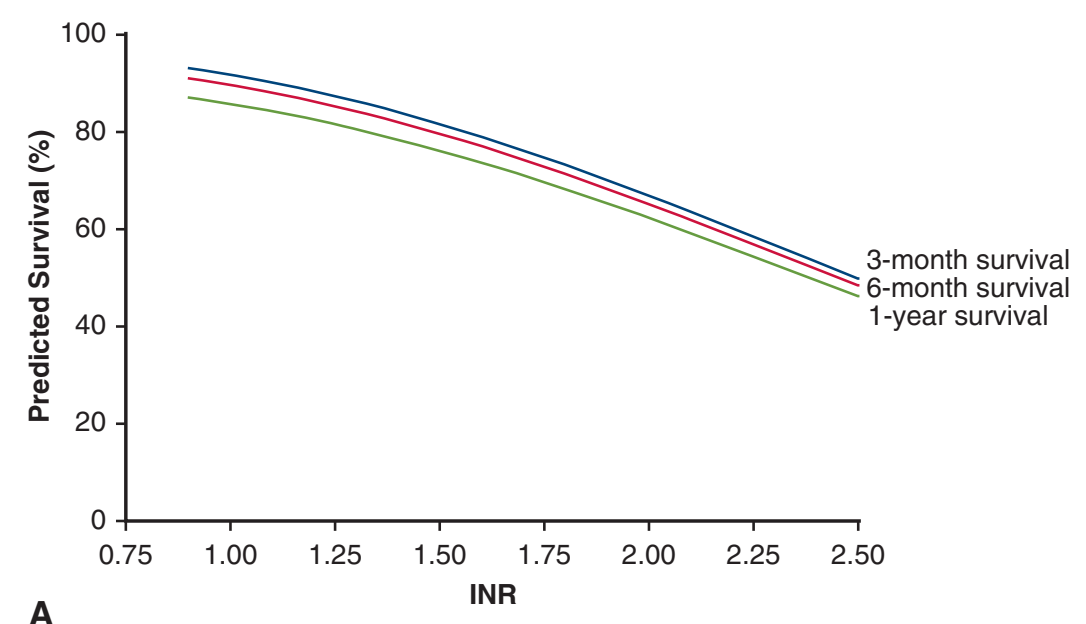

A
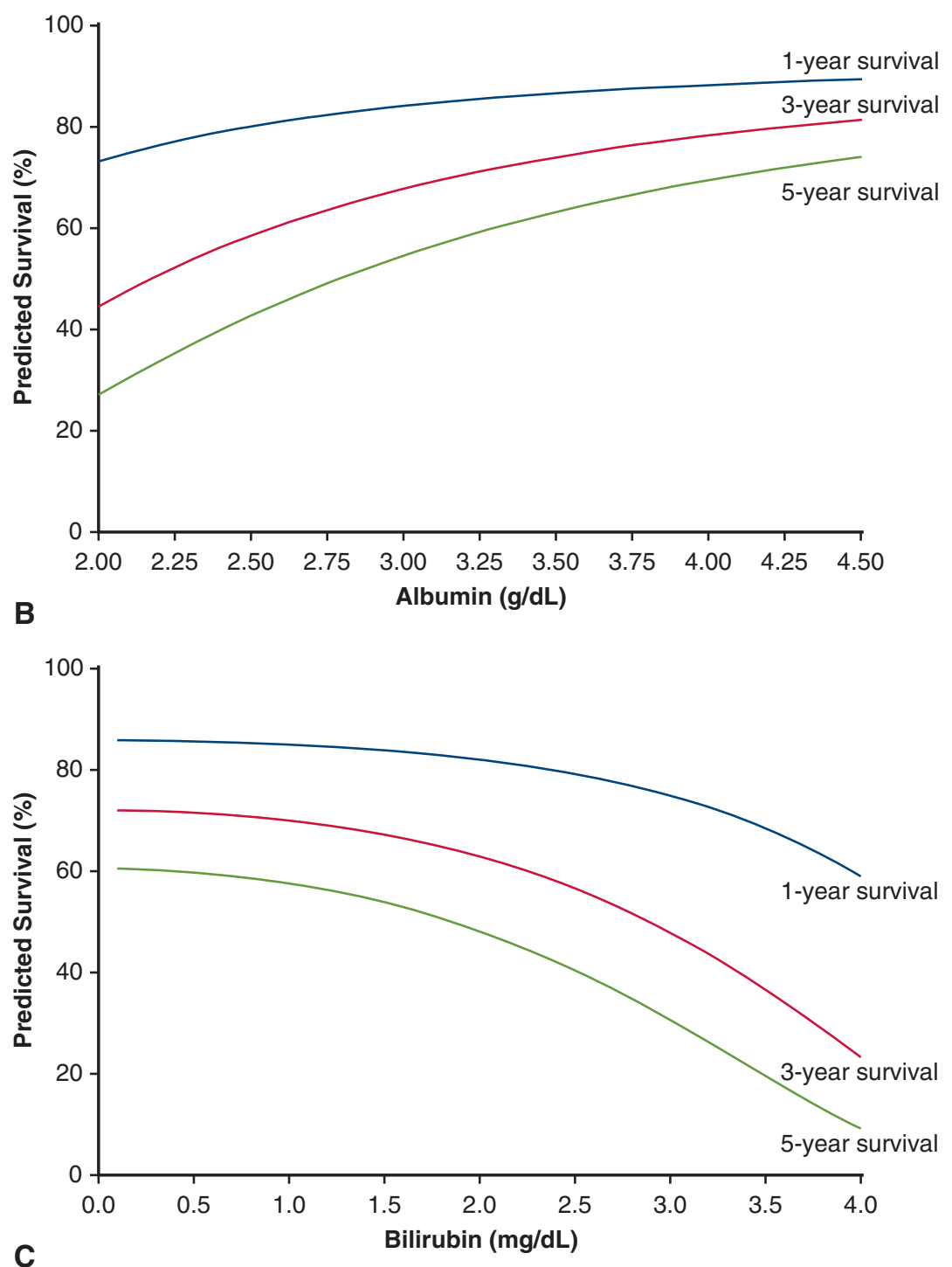

FIGURE E7. Risk-adjusted nomograms of predicted survival at various time points after transplant for urgently listed patients based on Table E4. A, Effect of INR on 3-month, 6-month, and 1-year survival. Albumin $=3.3 \mathrm{~g} / \mathrm{dL}$, bilirubin $=0.4 \mathrm{mg} / \mathrm{dL}$. B, Effect of albumin on 1-, 3-, and 5-year survival. INR $=1.0$, bilirubin $=0.4 \mathrm{mg} / \mathrm{dL}$. C, Effect of bilirubin on 1-, 3-, and 5-year survival. Albumin $=3.3 \mathrm{~g} / \mathrm{dL}$, INR $=1.0$. INR, International normalized ratio. 
TABLE E1. Variables associated with urgent versus elective listing

\begin{tabular}{lccc}
\hline \multicolumn{1}{c}{ Variable } & Estimate $\pm \mathbf{S E}$ & $\mathbf{P r}>\boldsymbol{\chi 2}$ & $\begin{array}{c}\text { Reliability, } \\
\% *\end{array}$ \\
\hline Higher lung allocation score & $0.037 \pm 0.0088$ & $<.0001$ & 94 \\
Higher creatinine clearance $^{\dagger}$ & $1.5 \pm 0.40$ & .0002 & 65 \\
\hline Higher blood urea nitrogen & $0.044 \pm 0.015$ & .004 & 51 \\
\hline In hospital & $3.8 \pm 0.52$ & $<.0001$ & 76 \\
In intensive care unit & $3.5 \pm 0.58$ & $<.0001$ & 76 \\
Diabetes & $0.72 \pm 0.28$ & .001 & 75 \\
\hline
\end{tabular}

$S E$, Standard error; $P r$, probability. *Percent of times factor appeared in 1000 bootstrap models. $\dagger \mathrm{Ln}$ (creatinine clearance), logarithmic transformation.
TABLE E2. Incremental risk factors for competing events after urgent listing

\begin{tabular}{lrrc}
\hline \multicolumn{1}{c}{ Risk factor } & $\begin{array}{c}\text { Coefficient } \\
\pm \text { SE }\end{array}$ & $\begin{array}{c}\boldsymbol{P} \\
\text { value }\end{array}$ & $\begin{array}{c}\text { Reliability, } \\
\% *\end{array}$ \\
\hline Death on waitlist & & & \\
$\quad$ Early phase & & & \\
$\quad$ Older age $\dagger$ & $1.2 \pm 0.33$ & .0002 & 50 \\
$\quad$ Higher bilirubin $\ddagger$ & $0.56 \pm 0.15$ & .0003 & 57 \\
$\quad$ Transfer from another & $1.6 \pm 0.31$ & $<.0001$ & 72 \\
$\quad$ institution & & & \\
Constant phase & & & \\
$\quad$ Higher MELD score $\S$ & $0.32 \pm 0.081$ & $<.0001$ & 57 \\
Transplanted & & & \\
$\quad$ Early phase & & & \\
$\quad$ Not transferred from & $1.03 \pm 0.31$ & .0008 & 95 \\
$\quad$ another institution & & & \\
$\quad$ No previous transfusion & $0.70 \pm 0.21$ & .001 & 64 \\
$\quad$ No inotropes & $0.87 \pm 0.26$ & .0009 & 86 \\
$\quad$ Higher eGFR & $0.99 \pm 0.21$ & $<.0001$ & 85 \\
\hline
\end{tabular}

$\overline{S E \text {, Standard error; } M E L D \text {, model for end-stage liver disease; } e G F R \text {, estimated }}$ glomerular filtration rate. *Percent of times factor appeared in 1000 bootstrap models.

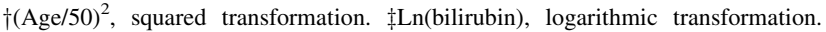
$\S(\text { MELD score/7.5) })^{2}$, squared transformation. "Ln(creatinine clearance), logarithmic transformation. 
TABLE E3. In-hospital outcomes in urgently listed and electively listed patients: weighted propensity-matched cohorts

\begin{tabular}{|c|c|c|c|c|c|}
\hline \multirow[b]{2}{*}{ Outcome } & \multicolumn{2}{|c|}{ Urgently listed (total $n=77$ ) } & \multicolumn{2}{|c|}{ Electively listed (total $\mathbf{n}=76$ ) } & \multirow[b]{2}{*}{$P$ value } \\
\hline & n* & No. $(\%)$ & n* & No. $(\%)$ & \\
\hline Death & 76 & $9.6(13)$ & 76 & $8.6(11)$ & .8 \\
\hline Stroke & 76 & $0.31(0.40)$ & 76 & $4.2(5.5)$ & .12 \\
\hline Atrial fibrillation & 76 & $28(37)$ & 76 & $29(38)$ & .8 \\
\hline Atrial flutter & 76 & $1.6(2.1)$ & 76 & $1.9(2.5)$ & .8 \\
\hline Myocardial infarction & 76 & $0(0)$ & 76 & $1.1(1.4)$ & - \\
\hline Reoperation for bleeding & 76 & $9.9(13)$ & 76 & $7.0(9.3)$ & .4 \\
\hline Reoperation for tamponade & 76 & $1.7(2.2)$ & 76 & $0.92(1.2)$ & 6 \\
\hline Respiratory distress & 76 & $0(0)$ & 76 & $0.32(0.43)$ & - \\
\hline Respiratory failure & 76 & $0.11(0.14)$ & 76 & $2.0(2.6)$ & .3 \\
\hline Intra-/postoperative ECMO & 76 & $3.9(5.1)$ & 76 & $5.2(6.9)$ & .6 \\
\hline \multicolumn{6}{|l|}{ Primary graft dysfunction } \\
\hline Grade at T0 & 74 & & 73 & & .5 \\
\hline 0 & & $30(40)$ & & $22(30)$ & \\
\hline 1 & & $11(15)$ & & $12(17)$ & \\
\hline 2 & & $3(4.3)$ & & $13(18)$ & \\
\hline 3 & & $29(40)$ & & $25(35)$ & \\
\hline Grade at T24 & 75 & & 72 & & .06 \\
\hline 0 & & $37(49)$ & & $20(28)$ & \\
\hline 1 & & $13(18)$ & & $25(35)$ & \\
\hline 2 & & $6.9(9.2)$ & & $11(16)$ & \\
\hline 3 & & $16(22)$ & & $14(19)$ & \\
\hline Grade at T48 & 74 & & 72 & & .02 \\
\hline 0 & & $33(45)$ & & $14(20)$ & \\
\hline 1 & & $19(26)$ & & $33(45)$ & \\
\hline 2 & & $7.6(10)$ & & $12(17)$ & \\
\hline 3 & & $13(18)$ & & $11(15)$ & \\
\hline Grade at T72 & 72 & & 70 & & .18 \\
\hline 0 & & $30(42)$ & & $18(26)$ & \\
\hline 1 & & $20(28)$ & & $30(44)$ & \\
\hline 2 & & $8.6(12)$ & & $11(17)$ & \\
\hline 3 & & $12(17)$ & & $8.6(12)$ & \\
\hline \multicolumn{6}{|l|}{ Length of stay, $\mathrm{d} \dagger$} \\
\hline Intensive care unit & 69 & $7[3,38]$ & 69 & $10[3,55]$ & .17 \\
\hline Postoperative & 76 & $23[11,60]$ & 76 & $24[12,65]$ & .2 \\
\hline
\end{tabular}

ECMO, Extracorporeal membrane oxygenation. *Patients with data available. †Median [15th, 85th percentiles].

TABLE E4. Incremental risk factors (baseline) for death after urgent lung transplant

\begin{tabular}{lccc}
\hline \multicolumn{1}{c}{ Factor } & Coefficient $\pm \mathbf{S E}$ & $\boldsymbol{P}$ value & Reliability, \%* \\
\hline $\begin{array}{l}\text { Early phase } \\
\quad \text { Higher INR } \dagger\end{array}$ & $2.6 \pm 1.2$ & .03 & 60 \\
Constant phase & & & \\
$\quad$ Lower albumin $\ddagger$ & $-2.0 \pm 0.39$ & $<.0001$ & 69 \\
Higher bilirubin $\S$ & $0.10 \pm 0.015$ & $<.0001$ & 69 \\
\hline
\end{tabular}

$\overline{S E \text {, Standard error; } I N R \text {, international normalized ratio. *Number of times factor ap- }}$ peared in 1000 bootstrap models. $\dagger(\log [\mathrm{INR}])$, logarithmic transformation. $\ddagger(\log$ [Albumin]), logarithmic transformation. $\S(\text { Bilirubin })^{2}$, squared transformation. 